\title{
Targeted therapy of gastroenteropancreatic neuroendocrine tumours: preclinical strategies and future targets
}

\author{
E T Aristizabal Prada and C J Auernhammer \\ Department of Internal Medicine IV, Campus Grosshadern, University-Hospital, Ludwig-Maximilians-University of Munich, Munich, Germany \\ Correspondence should be addressed to C J Auernhammer: christoph.auernhammer@med.uni-muenchen.de
}

\begin{abstract}
Molecular targeted therapy of advanced neuroendocrine tumours (NETs) of the gastroenteropancreatic (GEP) system currently encompasses approved therapy with the mammalian target of rapamycin (mTOR) inhibitor everolimus and the multi-tyrosinkinase inhibitor sunitinib. However, clinical efficacy of these treatment strategies is limited by low objective response rates and limited progression-free survival due to tumour resistance. Further novel strategies for molecular targeted therapy of NETs of the GEP system are needed. This paper reviews preclinical research models and signalling pathways in NETs of the GEP system. Preclinical and early clinical data on putative novel targets for molecular targeted therapy of NETs of the GEP system are discussed, including PI3K, Akt, mTORC1/ mTORC2, GSK3, c-Met, Ras-Raf-MEK-ERK, embryogenic pathways (Hedgehog, Notch, Wnt/beta-catenin, TGF-beta signalling and SMAD proteins), tumour suppressors and cell cycle regulators ( $p 53$, cyclin-dependent kinases (CDKs) CDK4/6, CDK inhibitor p27, retinoblastoma protein $(\mathrm{Rb})$ ), heat shock protein HSP90, Aurora kinase, Src kinase family, focal adhesion kinase and epigenetic modulation by histone deacetylase inhibitors.
\end{abstract}

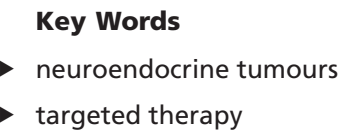

Endocrine Connections (2018) 7, R1-R25

\section{Introduction}

Neuroendocrine tumours (NETs) of the gastroenteropancreatic (GEP) system are often metastasized at the time of diagnosis and curative resection is not possible in all cases $(1,2)$. Our knowledge on medical therapy of advanced disease of NETs of the GEP system $(2,3,4,5,6,7,8)$, including molecular targeted therapy with the mammalian target of rapamycin (mTOR) inhibitor everolimus and the multi-tyrosinkinase inhibitor sunitinib, has significantly progressed over the last few years. Hallmarks of gastrointestinal NET development have been defined $(9,10)$ and our understanding of genetics $(11,12,13)$, epigenetics $(14,15)$, tumourigenesis (9), angiogenesis (9), novel biomarkers (10) and how to overcome resistance mechanisms $(16,17,18)$ has tremendously grown in the last few years. However, clinical efficacy of molecular targeted therapy with the mTOR inhibitor everolimus and the multityrosinkinase inhibitor sunitinib in NETs of the GEP system is limited by low objective response rates and limited progression-free survival (PFS) due to tumour resistance $(2,5,16,17)$.

Further novel strategies for molecular targeted therapy of NETs of the GEP system are needed. This review is focused on novel putative targeted therapies for well-differentiated NETs with G1/G2 grading of the GEP system $(19,20)$. We review current preclinical and early clinical data on several putative novel targets and future challenges for molecular targeted therapy of NETs of the GEP system.

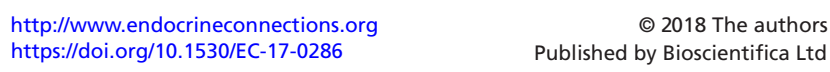




\section{Novel targets and future strategies in NETs}

\section{Preclinical in vitro and in vivo model in NETs}

Preclinical models of NETs currently encompass only a limited number of human NET cell lines and mouse models, as has been recently reviewed $(21,22,23,24)$. The most commonly used human neuroendocrine neoplasia cell lines of GEP origin encompass the pancreatic cell lines BON1 (25) and QGP1 (26), as well as the small intestinal cell lines GOT1 (27) and KRJ-I (28). The human insulinoma cell line CM has been reported to be not a valid model of beta cell function and to not secrete insulin because of severe chromosomal aberrations (29). Further human NET cell lines established are the small intestinal cell lines P-STS, L-STS and H-STS (30) and the neuroendocrine carcinoma cell lines NEC-DUE1, NEC-DUE2 (31) and N-TAK1 (32). Whole-exome characterisation of human pancreatic NET cell lines BON1 and QGP1 and human carcinoid lung cell lines, e.g. H727, has been reported $(33,34)$. A major limitation of the available human NET cell lines is that their mutation rate and pattern seem distinct from well-differentiated NETs in patients $(33,34)$ and thus might not adequately depict the tumour biology of well-differentiated NETs.

\section{Cell-signalling pathways in GEP-NETs}

\section{PI3K-Akt-mTOR pathway}

The PI3K-Akt-mTOR pathway is well known to be critical in GEP-NETs and offers promising mechanistic research approaches and therapeutic targets (35). Molecular targeting of the PI3K-Akt-mTOR pathway opened up new perspectives for therapeutic strategies and presented a vast variety of drugable pharmacologic targets (Table 1) as this pathway is involved in the pathogenesis and tumour growth of NETs $(16,36,37,38)$ (Fig. 1).

\section{Overactivation of the PI3K-Akt-mTOR pathway in} GEP-NETs Genetic mutations in the PI3K-Akt-mTOR pathway show an overall occurrence of $15 \%$ and an altered gene expression pattern in pancreatic NETs $(13,35)$. Gene amplification of PI3K-Akt-mTOR signalling components, mostly because of Akt 1 and Akt 2 amplifications, has been demonstrated to be common in small intestine NETs (SI-NETs) in approximately 33\% (16/48 tumours) (11). The dysregulations of Akt because of point mutations, gene amplification and/or overexpression, which result in the constitutive activation of Akt, lead to radio-resistance in cancers; an enhanced PI3K-Akt-mTOR pathway expression causes accelerated DNA double-strand break repair, which forms the radio-/chemo-resistance base (39). Misregulation in the PI3K-Akt-mTOR signalling pathway usually occurs because of constitutive activation of PI3K, for example because of downregulation and/or mutational loss of function of PTEN which then leads to unregulated activation of Akt (40). The upstream mTOR regulators PTEN and TSC2 are often mutated, downregulated or altered in their protein expression level, causing mTOR activation in pancreatic NETs $(41,42)$. Loss of PTEN protein was evidenced in $63 \%$ of small cell neuroendocrine carcinomas (17/27), with 38\% (5/13) exhibiting allelic loss (43). An immunohistochemical (IHC) analysis showed expression and activity levels of mTOR, 4EBP1, cytoplasmic phospho-4EBP1 (p4EBP1), nuclear p4EBP1, phospho-S6K (pS6K) and phospho-eIF4E (peIF4E) in GEP-NETs and demonstrated that 61, 93, 80, 69, 57 and $79 \%$ of the analysed GEP-NETs were positive for these proteins, respectively (44). Another IHC analysis of 72 primary pancreatic NETs showed a downregulation of TSC2 and/or PTEN in $85 \%$ of the cases, which was clearly correlated with shorter disease-free and overall survival (41). High mTOR activity was correlated with an enhanced proliferative capacity, and differences in mTOR activity and expression levels were associated with the possible variation in mTOR inhibitor response (44). Another IHC study correlated the expression of mTOR and its downstream targets RPS6KB1, RPS6 and eIF4EBP1 with an adverse clinical outcome in NETs (45). In an IHC study of ileal NETs, a clear overexpression of mTOR was determined in $76.2 \%$ of all cases (46).

Inhibition of the PI3K-Akt-mTOR pathway in GEP-NETs Inhibition of mTORC1 by rapamycin and its analogues is an effective anti-tumoural strategy in NETs. The mTORC1 inhibitor everolimus is currently approved for treatment of pancreatic NETs (47) and also of GI-NETs and lung NETs $(48,49)$. Sensitivity of cancer cells to rapamycin and its analogues is positively correlated with PIK3CA and/or PTEN mutations and with PI3K-Akt-mTOR activation demonstrated by high pAkt and p70S6K levels $(50,51)$. Following treatment with rapamycin and its analogues, a compensatory upregulation of the PI3K-Akt cascade with an increase in p-Akt T308 and pAkt S473 is observed in rapamycinsensitive cancer cells but not in rapamycin-insensitive cancer cells $(50,51)$. On the other hand, this upregulation of p-Akt during treatment with rapamycin and its analogues is an important compensatory mechanism,

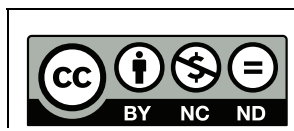

This work is licensed under a Creative Commons Attribution-NonCommercial-NoDerivatives 4.0 International License. 
Table 1 Molecular targeting therapies of the PI3K-Akt-mTOR pathway in GEP-NETs.

\begin{tabular}{l|l} 
Target & $\frac{\begin{array}{l}\text { Immunohistochemical } \\
\text { data }\end{array}}{\text { KTORC1 }}$ \\
$\begin{array}{l}\text { Kasajima et al. (44), } \\
\text { Geis et al. (46) }\end{array}$
\end{tabular}

$\mathrm{PI3K}$ mTORC1/mTORC2

Missiaglia et al. (41), PI3K upregulation; Pitt et al. (40), Cingarlini et al. (42), Tan et al. (43)

Akt

\begin{tabular}{l}
$\begin{array}{l}\text { Gene expression/ } \\
\text { somatic mutations }\end{array}$ \\
\hline mTOR upregulation
\end{tabular}
PTEN/TSC2 downregulation/ mutational loss of function Banck et al. (11)

\begin{tabular}{l} 
Substance: in vitro data \\
Human NET cell lines \\
\hline Everolimus \\
Passacantilli et al. (58), \\
Grozinsky-Glasberg \\
et al. (68), Zitzmann \\
et al. (69), \\
Djukom et al. (70) \\
Temsirolimus \\
Rapamycin \\
Moreno et al. (66)
\end{tabular}

Substance: in vivo

LY294002

Djukom et al. (70),

Couderc et al. (71)

BKM120

Valentino et al. (73)

BEZ235

Gagliano et al. (51),

Zitzmann et al. (56),

Passacantilli et al. (58),

Valentino et al. (73)

BYL719

Passacantilli et al. (58)

Perifosine

Zitzmann et al. (78)

MK-2206

Somnay et al. (79)

Triciribine

Gloesenkamp et al. (82) data Animal model

Everolimus

Djukom et al. (70)

Pool et al. (267)

Rapamycin

Moreno et al. (66)

Clinical trials

Everolimus

(phase 3)

Yao et al. (47)

Pavel et al. (48)

Yao et al. (49)

Temsirolimus

(phase 2)

Hobday et al.

(268),

Duran et al. (52)

LY294002

BEZ235 (phase2)

Djukom et al. (70), Fazio et al. (60)

Couderc et al. (71) CC-223 (phase 1)

Mita et al. (83)

MK-2206 (phase

1, 2)

Yap et al. (80),

Reidy-Lagunes

et al. (81) causing treatment resistance $(52,53,54,55,56,57,58$, $59,60)$. Thus, the anti-tumoural efficacy of mTORC1 inhibitors as everolimus or temsirolimus is limited, most probably because of rescue mechanisms, including compensatory upregulation of PI3K-Akt signalling and Ras-Raf-MEK-ERK1/2 signalling by mTORC1 inhibitors $(52,53,54,55,56,57,58,59,60,61)$. The better understanding of long-term resistance formation to everolimus treatment is of fundamental importance to establish predictive biomarkers and to provide rationale dual targeting options in order to overcome such acquired or intrinsic resistance $(53,62)$. Because of the importance of the PI3K-Akt-mTOR pathway in GEP-NENs, many possible therapeutic targets open up on many different levels along the signalling pathway and further research is required. Dual horizontal inhibition of the PI3K-Akt-mTOR signalling cascade as well as dual vertical inhibition of mTORC1 and other pathways as Ras-Raf-MEK-ERK1/2 signalling might be a promising future strategy to overcome compensatory rescue mechanisms and resistance in NETs.

mTOR inhibition The mTOR has an essential role in cell growth control and involvement in human

$$
\begin{array}{lr}
\text { http://www.endocrineconnections.org } & \text { ○ } 2018 \text { The authors } \\
\text { https://doi.org/10.1530/EC-17-0286 } & \text { Published by Bioscientifica Ltd }
\end{array}
$$

tumourigenesis. It is involved in two distinct multiprotein complexes, namely mTORC1 and mTORC2 $(63,64)$. While mTORC1 is stimulated by various growth factors and is sensitive to inhibition by rapamycin and its analogues, mTORC2 is considered insensitive to rapamycin and its analogues $(63,64)$.

The role of mTORC1 inhibition in GEP-NETs has been recently extensively reviewed by Briest and coworkers. (65). Using various preclinical in vitro and in vivo models of NETs, anti-tumoural effects have been demonstrated for rapamycin (66) and everolimus (58, $67,68,69,70)$. mTORC1 inhibition in NETs causes dephosphorylation of the mTORC1 downstream signals p70S6K and 4EPB1, and compensatory upregulation of the upstream signal Akt $(52,55,56,66)$. Dual targeting within the same pathway (vertical targeting) or within different pathways (horizontal targeting) seems to be a possible solution for de novo or acquired mTORC1 inhibitor resistance and for inhibition escape mechanisms (35).

PI3K inhibition Preclinical studies in NET cell lines in vitro and xenograft mouse model in vivo have demonstrated anti-tumoural efficacy of the PI3K inhibitor

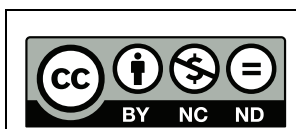

This work is licensed under a Creative Commons Attribution-NonCommercial-NoDerivatives 4.0 International License. 


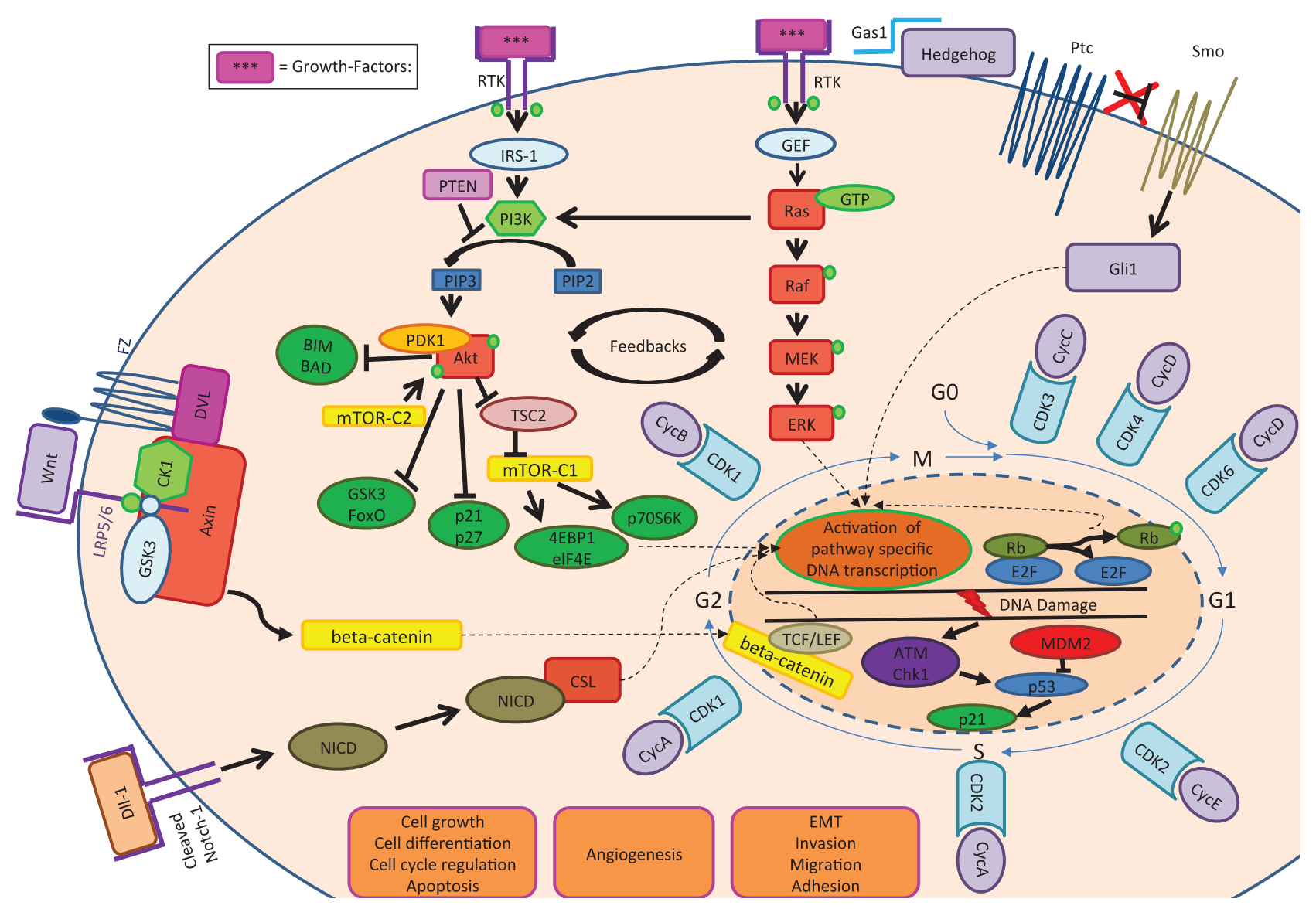

Figure 1

Important growth factors and cellular signalling pathways involved in tumourigenesis and angiogenesis of NETs. PI3K-Akt-mTOR pathway, Ras-RafMEK-ERK pathway, Wnt/beta-catenin pathway, Notch-1 signalling and Hedgehog signalling, cyclin-dependent kinases in a cellular context.

LY294002 alone and in combination with the mTORC1 inhibitors rapamycin or everolimus $(70,71)$. In RIP1-Tag2, the selective inactivation of the $\mathrm{p} 110 \alpha$ PI3K isoform, either genetically or pharmacologically (GDC-0326), decreased tumour growth and vascular area, and GDC-0326 reduced the incidence of liver and lymph node metastasis compared with vehicle-treated mice (72). In vitro studies also demonstrated the pan-PI3K inhibitor BKM120 (73) and the dual PI3K/mTOR inhibitor BEZ235 alone and in combination with the mTORC1 inhibitor everolimus (51, $56,58,73)$ to exert anti-tumoural efficacy in NET cells. In human NET cell lines, the PI3K inhibitors BEZ235, BKM120 and BYL719 were tested in combination with RAD001 to overcome feedback resistance mechanisms occurring often by sole mTOR inhibition $(58,74)$. In another study, different NET cell lines were treated with either the panPI3K inhibitor BKM120 or the dual PI3K/mTOR inhibitor BEZ235 alone or in combination with the MEK inhibitor, PD0325901 (73), the combination of BEZ235 and PD0325901 was the most effective therapy option in vivo

$$
\text { http://www.endocrineconnections.org }
$$

compared with single-agent treatments demonstrating the great potential of horizontal combinational targeting (73). However, the clinical development of BEZ235 was terminated, and two clinical phase 2 studies in NETs did not meet the statistical endpoint and demonstrated severe toxicity $(60,75)$. Nevertheless, targeting PI3K in NETs with other compounds still might be a promising approach. Further agents and inhibitors concerning PI3K or other upstream targets that are recently in clinical trials should also be tested for therapeutic approaches in GEP-NETs $(65,76)$. Currently, there is only one FDA-approved deltaspecific PI3K inhibitor (idelalisib) used in leukaemia and two types of lymphoma, but there are over 30 PI3K inhibitors at different stages in clinical trials, belonging to either a dual pan-Class I PI3K/mTOR inhibitor, a panClass I PI3K inhibitor lacking significant mTOR activity or an isoform-selective PI3K inhibitor (77).

Akt-inhibition The pan-Akt inhibitor perifosine demonstrated strong anti-tumoural effects in vitro in

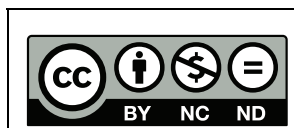
This work is licensed under a Creative Commons
Attribution-NonCommercial-NoDerivatives 4.0 International License. 
human NET cell lines and a particular role of Akt1 and Akt3 isoforms was determined because of knockdown methods with siRNA, suggesting a therapeutic potential by selective Akt1/Akt3 targeting (78). In vitro studies with the allosteric pan-Akt inhibitor MK-2206 in NET cell lines demonstrated a decrease in pAKT expression, inhibition of proliferation and induction of apoptosis mechanisms and a decreased expression of the NET tumour markers CgA and NSE (79). In a clinical phase 1 study with MK-2206 in patients with solid tumours, two patients with pancreatic NETs experienced a minor tumour response (80). A clinical phase 2 study with MK-2206 including eight patients with NETs (NCT01169649) was terminated early by the sponsor and demonstrated minor response/stable disease in 4/8 (50\%) with a range from 4.2 to 10.2 months (81). In insulinoma CM cells and gut neuroendocrine STC-1 cells, the Akt inhibitor triciribine decreased cell growth and showed synergistic antiproliferative effects in combination with 5-fluorouracil or the mTORC1 inhibitor everolimus or the IGF-1R inhibitor NVP-AEW541 (82).

mTORC1/mTORC2 inhibition In a phase 1 clinical trial expansion with the mTORC1/mTORC2 inhibitor CC-223 on non-pancreatic NETs, prolonged stable disease and symptomatic improvement in subjects with refractory carcinoid syndrome were reported (83). The highly selective dual inhibitor of PI3K and mTORC1/mTORC2 PKI-587 has shown promising anti-proliferative effects in a study with various NET cell lines (BON1, QGP1, KRJ-I and LCC-18) (84).

Combination of $\mathrm{mTORC} 1$ and EGFR inhibition Everolimus exhibited synergistic effects in combination with the EGFR inhibitor erlotinib on large-cell NETs and bronchial NETs with an activated EGFR-Akt-mTOR pathway by inducing apoptosis (61). Dual therapeutic targeting of EGFR and mTOR in a preclinical mouse model with pancreatic NETs could overcome drug resistance and improve survival (85).

\section{Combination of $\mathrm{mTORC1}$ and somatostatin} analogues Treatment of NET cells in vitro with a combination of the mTORC1 inhibitor rapamycin or everolimus plus the somatostatin analogue octreotide has caused controversial results in different models. The combination of mTORC1 inhibitors plus octreotide caused no enhanced anti-tumour activity in comparison to mTORC1 inhibition alone in human NET cell lines BON1 and H727 $(66,68,86)$ and primary tumour cells in vitro. The lack of effect of octreotide in BON1 and H727

$\begin{array}{lr}\text { http://www.endocrineconnections.org } & \text { ( } 2018 \text { The authors } \\ \text { https://doi.org/10.1530/EC-17-0286 } & \text { Published by Bioscientifica Ltd }\end{array}$

cells might be because of the fact that these cell lines do not express a sufficient amount of somatostatin receptor type 2 (87) and it does not seem an appropriate model in this setting. In contrast, in the human SI-NET cell lines KRJ-I and H-STS in vitro everolimus and octreotide alone, each showed anti-tumoural effects, while everolimus plus octreotide caused an enhanced anti-tumoural activity (55). However, an escape feedback loop activation was encountered in KRJ-I and H-STS cells following treatment with everolimus or everolimus plus octreotide, so dual targeting with everolimus plus octreotide could not overcome the pAkt-pERK1/2-mediated escape mechanisms (55). In a clinical phase 3 trial, there was no significant superior effect of combined treatment with everolimus plus octreotide LAR versus placebo plus octreotide LAR in patients with NETs and carcinoid syndrome (48).

Combination of mTORC1 and VEGF inhibition The preclinical rationale for the combination of mTORC1 inhibition and inhibition of VEGF signalling and its possible role to overcome resistance mechanisms has been extensively reviewed by Cella and coworkers (18). Current clinical trials with VEGFR inhibition in patients with NETs have been recently reviewed by Pavel and coworkers (76).

Other mTOR inhibitors: aspirin and metformin AMPactivated protein kinase (AMPK) is a highly conserved key regulator implicated in cellular homeostasis, cell growth and cytoskeletal and cell death mechanisms (88). AMPK activation causes downregulation of mTOR and S6K phosphorylation and generates overall mRNA translation reduction and protein synthesis decrease, making it a possible target for anti-cancer approaches (88). In this context, metformin $(89,90,91)$ and aspirin (92), as well as several other drugs like phenformin, resveratrol, berberine, statins, epigallocatechin gallate and capsaicin, have been suggested to exert anti-tumoural effects by activation of AMPK and inhibition of mTOR (93).

In the human NET cell lines BON1, GOT1 and NCI$\mathrm{H} 727$ in vitro incubation with aspirin caused decreased cell viability/proliferation because of cell cycle arrest mechanisms with mTOR downstream signalling suppression (67). Preclinical in vivo data in the Rip1-Tag2 mouse model causing pancreatic NETs showed a significant inhibition of tumour proliferation by aspirin or enalapril alone, while the combination of aspirin and enalapril was the most efficient regarding tumour size reduction and prolonged overall median survival (94). An epidemiologic study reported use of aspirin as a protective factor with a 
risk reduction for the development of SI-NETs (HR 0.20; 95\% CI 0.06-0.65, $P=0.008)(95)$.

In vitro incubation with metformin caused decreased cell viability/proliferation in BON1, GOT1 and H727 cells, because of cell cycle arrest mechanisms with mTOR downstream signalling suppression (96). In prospect of evaluating the possible anti-proliferative effect of metformin in combination with everolimus and octreotide LAR in well-differentiated pancreatic NET patients, a single-centre phase 2 study was designed (MetNET-1 trial, NCT 02294006) (97). First findings of the PRIMENET study suggest that the combination of metformin with everolimus and/or somatostatin analogues can cause a clinical benefit in diabetic NET patients (98). The MetNET-2 trial (NCT02823691) was designed to evaluate the safety of metformin in combination with lanreotide in well-differentiated gastrointestinal and lung NETs (98).

\section{GSK3}

The glycogen synthase kinase 3 (GSK3), with its two isoforms alpha (GSK3- $\alpha$ ) and beta (GSK3- $\beta$ ), unlike most other kinases is active in its non-phosphorylated state (99). Various studies have demonstrated an association between GSK3 deregulation and tumourigenesis $(99,100)$. However, as has been recently reviewed, GSK3 plays an ambiguous role as an tumour suppressor or oncogene, respectively. This has limited the use of GSK3 inhibitors in targeted therapy of cancer including GEP-NETs, so far (99) (Table 2). GSK3 is involved in various major NET pathways, such as Wnt/beta-catenin, PI3K-Akt-mTOR and Ras-Raf-MEK-ERK, Hedgehog and Notch signalling (99). Treatment with the GSK3 inhibitors CHIR99021, 6-bromoindirubin-3'oxime-, 1-azakenpaullone and siRNA enhanced the proliferative growth of rat insulinoma INS-1E cells (101). On the other hand, the non-specific GSK3 inhibitor lithium chloride showed NET growth inhibition in vitro and in vivo (102, 103). Similarly, in gastrointestinal and pulmonary tumour cell lines, dual targeting with lithium chloride and histone deacetylase (HDAC) inhibitors leads to enhanced anti-proliferative effects through GSK3 inhibition/phosphorylation and Notch-1 expression (104). Further unspecific GSK3 inhibitors such as lithium chloride, SB415286 or kenpaullone decreased cellular proliferation in different rodent insulinoma cell lines through a G2/M cell cycle arrest and apoptosis (105). Furthermore, substances such as MG-132 (106), ZM336372 (107), metformin (96) and aspirin (67) blocked NET cell growth possibly through GSK3 inhibition. Despite these promising preclinical

$$
\begin{array}{lr}
\text { http://www.endocrineconnections.org } & \odot 2018 \text { The authors } \\
\text { https://doi.org/10.1530/EC-17-0286 } & \text { Published by Bioscientifica Ltd }
\end{array}
$$


data, a clinical phase 2 study in 15 patients with lowgrade NETs treated with lithium chloride $300 \mathrm{mg}$ tid p.o. caused no objective responses and a median PFS of only 4.5 months and pre- and post-treatment tumour biopsies showed no consistent GSK3- $\beta$ inhibitory effects (103). This might be because of the serum levels of lithium chloride reached in humans being not sufficient to phosphorylate and inhibit GSK3 (103). Hence, preclinical and clinical studies considering more potent and specific GSK3 inhibitors need to be evaluated as possible novel targets for NETs.

\section{Hepatocyte growth factor (HGF)/c-Met signalling}

The MNNG HOS transforming gene (MET) is a receptor tyrosine kinase and HGF is its ligand $(108,109)$. Tumour hypoxia upregulates hypoxia-inducible factors (HIFs) and induces overexpression of c-Met in tumours, while inhibition of Met expression prevents hypoxia-induced invasive growth $(108,109)$. c-Met is involved in tumour cell survival, invasion, motility and metastasis formation in cancers $(108,109)$. Upregulation of c-Met contributes to resistance of tumour cells $(108,109)$.

Dual targeting of VEGF and c-Met signalling has been discussed to synergistically contribute to anti-tumoural effects in pancreatic NETs in RIP-Tag2 mice (110, 111, 112). VEGF inhibition only inhibited tumour growth but increased expression of HIF- $1 \alpha$ and c-Met activation and increased tumour invasion and metastasis (110, $111,112)$. In contrast, treatment with the dual VEGFR/ c-Met inhibitor cabozantinib (XL184) or the c-Met inhibitor PF-04217903 reduces invasion and metastasis $(110,111,112)$. In the human NET cell lines BON1 and H727 in vitro, the highly specific c-Met inhibitor Inc280 $(113,114)$ did not cause inhibition of cell proliferation (115), while cabozantinib and tivantinib exhibited anti-proliferative effects in BON1 and H727 cells, most probably mediated by 'off-target' effects not mediated by c-Met inhibition (115).

Currently, a clinical phase 2 trial investigates the role of cabozantinib in advanced pancreatic neuroendocrine and carcinoid tumours (NCT01466036).

\section{Ras-Raf-MEK-ERK pathway}

The Ras-Raf-MEK-ERK pathway belongs to the mitogenactivated protein kinase (MAPK) pathway system, is activated by various growth factors, is involved in cell growth and cell differentiation and represents a specific pharmacological target in oncology and possible

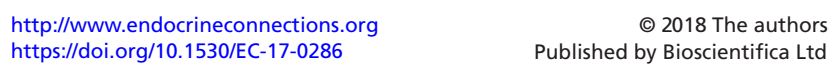

novel target for GEP-NET therapy, including clinical development of several Raf inhibitors and MEK inhibitors (116) (Fig. 1 and Table 3). Ras and Raf are considered proto-oncogenes and gains of function mutations lead to tumourigenesis and elevated cell transformation in many cancer entities (116). Cancers with activating mutations in BRAF are sensitive to Raf and MEK inhibition (116) and the BRAF inhibitors vemurafenib and dabrafenib and the MEK inhibitor trametinib have been licensed for the treatment of BRAFV600-mutated advanced melanoma $(116,117)$.

However, mutations of Ras $(13,118,119)$ are only very rare events in GEP-NETs with reported mutation frequencies (119) of HRas 1\% (2/150), KRas 8\% (10/125), NRas $0.7 \%$ (2/274) or BRaf 1\% (4/369). Neurofibromatosis (NF) type 1 is occasionally associated with the development of pancreatic NETs (120). NF type 1 is classified as a RasOpathy, as Ras-MAPK signalling is affected by mutations of the NF1 gene, encoding neurofibromin as an RAS GTPase-activating protein (121).

Preclinical in vitro studies in NET cells demonstrated that not only Raf inhibitors $(56,122)$ and MEK inhibitors $(57,73)$ but instead also Raf-1 activators $(107,123,124$, 125) might be of interest as potential target as has been extensively reviewed by Fazio and coworkers $(37,126)$. In BON1 cells, stable transfection with an oestrogeninducible Raf-1 construct (BON1-raf cells) caused an induction of MEK and ERK 1/2 signalling (127), induction of focal adhesion kinase (FAK) by an MEK/ERK1/2dependent pathway (128) and decreased CgA expression by an MEK/ERK1/2/FAK-dependent pathway $(127,128)$ and decreased cell adhesion and downregulation of beta-catenin by an MEK-dependent pathway $(128,129)$. ATP-competitive Raf inhibitors exert opposing functions as inhibitors or activators of MAPK signalling, depending on the BRAF mutational status of the tumour cell (130). While in BRAF-mutated cancer cells, ATP-competitive Raf inhibitors inhibit downstream MAPK signalling, in RAS/RAF wild-type tumour cells, ATP-competitive RAF inhibitors paradoxically activate MAPK signalling (130). In non-neuroendocrine cells (131) and in human BON1 tumour cells (107), the ATP-competitive Raf-1 inhibitor ZM336372 has been reported to cause upregulation of Raf-1 at the transcriptional level. Treatment of BON1 tumour cells with ZM336372 caused induction of phosphorylation of Raf-1, MEK and ERK1/2 (123), upregulation of p21 and p18 (123), suppression of cell proliferation (123) and reduced expression of NET markers CgA and achaete-scute complex-like 1 (ASCL1) (123). However, ZM336372 in BON1 cells also inactivates GSK3 at an

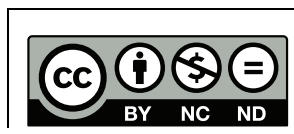

This work is licensed under a Creative Commons Attribution-NonCommercial-NoDerivatives 4.0 International License. 
Table 3 Targeting the Ras-Raf-MEK-ERK pathway in GEP-NETs.

\begin{tabular}{|c|c|c|c|}
\hline Target & Immunohistochemical data & $\begin{array}{l}\text { Gene expression/somatic } \\
\text { mutations }\end{array}$ & Substance: in vitro data Human NET cell lines \\
\hline Ras/Raf/MEK & $\begin{array}{l}\text { Gilbert et al. (118), Jiao et al. } \\
\text { (13), Vijayvergia et al. (269) }\end{array}$ & $\begin{array}{l}\text { HRAS/KRAS/NRAS/BRAF/NF1 } \\
\text { expression }\end{array}$ & $\begin{array}{l}\text { ZM336372 } \\
\text { Kunnimalaiyaan et al. (107), } \\
\text { Van Gompel et al. (123) } \\
\text { Teriflunomide } \\
\text { Cook et al. (124) } \\
\text { Raf265 } \\
\text { Zitzmann et al. (56), Zitzmann et al. (122) } \\
\text { PD0325901 } \\
\text { Valentino et al. (73) } \\
\text { UO126 } \\
\text { lida et al. (57) }\end{array}$ \\
\hline
\end{tabular}

Raf-MEK-independent pathway (107) and ZM336372induced reduction of CgA and ASCL1 expression has been shown to be mediated by an Raf-MEK-independent pathway (107); thus, the observed Raf-1 induction might not be essential for the anti-tumoural effects of ZM336372. The Raf- 1 activator teriflunomide has also been reported to show anti-proliferative effects in BON1 cells alone (124) and in combination with pasireotide (125).

The Ras-Raf-MEK-ERK pathway is a highly complex network interacting with other crucial cellular pathways such as the PI3K-Akt-mTOR pathway (65). Inhibition of mTORC1 causes compensatory upregulation of the MAPK pathway $(132,133,134)$, and dual horizontal inhibition of the mTORC1 and MAPK signalling has additive antitumoural effects in cancer cells. In NET cells in vitro, the Raf inhibitor Raf265 has been demonstrated to have antiproliferative activity $(56,122)$. Zitzmann and coworkers reported compensatory feedback loops on PI3K-AktmTOR pathway, when Raf-MEK-ERK signalling was inhibited in human NET cell lines (56). Combination of the mTORC1 inhibitor everolimus or the mTOR/PI3K inhibitor NVP-BEZ235 with the Raf inhibitor Raf265 was able to suppress Raf265-induced feedback mechanisms on pAkt and exerted enhanced anti-proliferative effects in comparison to single-substance treatment (56). Also synergistic effects of co-targeting the PI3K-AktmTOR and Ras-Raf-MEK-ERK pathway were obtained with the PI3K inhibitor BKM120 and the PI3K/mTOR inhibitor BEZ235 in combination with the MEK inhibitor PD0325901 in human neuroendocrine BON1, H727 and QGP1 cells in vitro and a BON1 xenograft model in vivo (73) and with the MTOR inhibitor RAD001 and the MEK inhibitor UO126 in human neuroendocrine NCI-H727 and COLO320 cells (57).

As controversial effects of Ras-Raf-MEK-ERK inhibition/activation on cancers seem to depend on

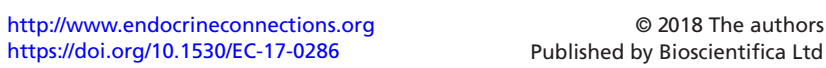

the tumour cell type specific context (126), further investigation of the possible benefits or problems of RasRaf-MEK-ERK signalling manipulation in GEP-NETs is still required.

\section{Pathways important not only during embryogenesis}

Hedgehog signalling The hedgehog (Hh) signalling pathway is implicated in a vast variety of biological processes reaching from embryogenesis to adult-tissue homeostasis and tumourigenesis. Misregulation of hedgehog signalling provokes numerous human disorders including tumourigenesis $(135,136)$ (Fig. 1).

Inhibitors of the $\mathrm{Hh}$ pathway, primarily Smo inhibitors, as vismodegib (GDC-0449), BMS-833923, saridegib (IPI-926), sonidegib/erismodegib (LDE225), PF-04449913, LY2940680, LEQ 506 and TAK-441 are in clinical development for cancer therapy $(137,138)$. Vismodegib is the first-in-class hedgehog pathway inhibitor licensed for metastatic or locally advanced basal cell carcinoma (139) and Gorlin-Goltz associated basal cell cancer (140). Further second-generation inhibitors of Hh signalling acting downstream of Smo are in development (137).

In GEP-NETs, embryological pathways like $\mathrm{Hh}$ are activated (141). Expression of sonic hedgehog (SHH) and one of its downstream targets Snail has been reported in 53\% (16/30) of SI-NETs (142). Protein expression of the $\mathrm{SHH}$ receptor PTCH1 was found in 55\% (12/22) of sporadic pancreatic NET tumour samples and in $80 \%(4 / 5)$ of MEN1-associated tumours patients (143). Expression levels of Ptch1 were not predictive for clinical outcome (143). Duodenal gastrinomas and associated metastases showed in 100\% (15/15) Shh expression, whereas no Shh expression was detected in 
pancreatic gastrinomas (144). In gastrointestinal NECs, Hh downstream target Gli1 expression was upregulated and IHC analysis showed $100 \%$ positive staining for Gli1 in NECs (12/12), whereas only $1 / 7$ adenocarcinoma was positive for Gli1, indicating the importance of $\mathrm{Hh}$ signalling in NEC formation (145). In vitro treatment with the $\mathrm{Hh}$ inhibitor cyclopamine caused Gli1, Ptch1, Snail and hASH1, mRNA levels to get downregulated (145). Permanent activation of Smo caused clonogenicity of SCLC in vitro, as well as the initiation and progression of mouse SCLC in vivo; additionally, pharmacological blockade of Hh signalling inhibited SCLC growth in vivo and in vitro after chemotherapy (146). In the multiple endocrine neoplasia type 1 (MEN1) tumour syndrome, an enhanced Hh signalling causes proliferation of pancreatic beta cells and susceptibility to pancreatic islet tumour formation (147). Functional menin blocks Hh signalling via PRMT5-mediated epigenetic suppression of the Gas1 gene (147), an important enhancer of the Hh signalling (148). Inhibition of Gli1 by the inhibitor GANT-61 caused decreased expression of Gli1 and its target genes in MEN1-depeleted cells (149). Thus, non-functional menin engenders Gas1 expression and thereby foments pro-proliferative and oncogenic Hh signalling, suggesting Menin/PRMT5/hedgehog signalling as a potential target for MEN1 treatment $(147,150)$.

The Smo antagonist cyclopamine (151, 152) effectively downregulated $\mathrm{Hh}$ target genes and suppressed cell proliferation in a murine Rip-Tag2 model of islet cell tumours (153) and in human NEC cells (145). Similarly, treatment with the orally bioavailable Smo antagonist sonidegib (LDE225) in the murine Rip-Tag2 model of islet cell tumours caused downregulation of $\mathrm{HH}$ downstream targets, tumour volume reduction of $95 \%$ and prolonged median overall survival (154). Also in GOT1, human small intestine NETs in nude mice treatment with sonidegib (LDE225) inhibited tumour growth (155). Sonidegib (LDE225) is currently licensed for the treatment of advanced basal cell carcinoma of the skin. A phase 1 trial to evaluate the safety and tolerability of LDE225 and octreotide LAR in patients with progressive NETs (AIONET-0114://www.aio-portal.de/index.php/175.html) has been closed.

Notch-1 signalling The Notch-1 signalling pathway is a highly conserved embryonic pathway that is important in juxtacrine signalling between neighbouring cells, regulates cell proliferation and cell differentiation and has been demonstrated to play an essential role in tumourigenesis and maintenance of cancer stem cells (CSCs) (136) (Fig. 1).
The role of Notch-1 signalling in NETs has been reviewed recently by Crabtree and coworkers (156).

The role of Notch-1 signalling in tumourigenesis is paradoxical and dependent upon the specific cancer cell type context, as Notch-1 has been demonstrated to function either as a tumour suppressor or as an oncogene, respectively $(157,158,159,160,161,162)$ :

1. In various haematologic and solid tumours, for example breast cancer and colon cancer, Notch-1 and its respective ligands are overexpressed and an oncogenic role of the Notch-1 gene has been shown (157, 158, 159, 163). Notch-1 signalling can be inhibited by specific antibodies against Notch-1 and its ligands as well as by gamma-secretase inhibitors, inhibiting cytoplasmatic Notch-1 intracellular domain formation and thus subsequent Notch-1 target gene activation (163, 164); these strategies are in clinical development in several cancer entities $(163,164)$.

2. In contrast, reduced/absent Notch-1 activity is found in carcinoid like NETs, pheochromocytomas and thyroid carcinomas and Notch-1 re-expression/reactivation has been demonstrated to exert anti-tumoural effects in these tumour entities (165). Therefore, Notch-1 activators are evaluated as potential pharmacological agents in some NETs (165).

Preclinical studies in human pancreatic carcinoid BON1 and bronchopulmonary carcinoid H727 tumour cells have demonstrated upregulation of Notch-1 expression to cause subsequent downregulation of the achaete-scute complex-like 1 (Ascl1) protein, inhibit the secretion of neuroendocrine markers and 5-hydroxytryptamine and inhibit tumour cell proliferation (166, 167, 168). In human carcinoid tumour samples, the Notch downstream target Ascl1 protein was overexpressed compared with surrounding normal tissue (169). Stable transfection of Notch-1 into pancreatic carcinoid BON1 cells reduces Ascl1 expression probably because of degradation (170), inhibits tumour cellular proliferation and decreases secretion of neuroendocrine markers as neuron-specific enolase, synaptophysin, chromogranin A, represses tryptophan hydroxylase 1 expression and decreases serotonin and 5-hydroxytryptamine secretion (166, 169). Ascl1 has been demonstrated to negatively regulate tryptophan hydroxylase 1 expression in BON1 cells (171), the rate limiting enzyme in the biosynthesis of serotonin (171).

The HDAC inhibitor valproic acid (VPA) activated Notch-1, blocked Ascl1 expression, lowered CgA expression, suppressed cell growth and caused cell cycle 
arrest because of a p21 and p27 increase and a cyclin D1 degradation in neuroendocrine gastrointestinal and pulmonary carcinoid cells in vitro (172). In addition, VPA also suppressed growth of carcinoid tumours in vivo in a mouse tumour xenograft (172). Similarly, VPA also activated Notch-1, blocked Ascl1 expression, decreased CgA expression and inhibited cell growth inhibition in SCLC tumour cells in vitro (173). Combination of the HDAC VPA and the GSK3 inhibitor lithium activated Notch-1 signalling and inactivated GSK3 activity in human NET cells in vitro and caused synergistic antiproliferative effects (104). In a clinical phase 2 study, eight patients with low-grade NETs were treated with VPA. Notch-1 signalling was absent in pretreatment tumour samples and upregulated following VPA treatment. Best response during VPA treatment was stable disease in 50\% (4/8) of the patients (174).

The grape antioxidant resveratrol has demonstrated to exhibit characteristics relevant for anti-cancer strategies (175). Resveratrol was identified and validated as a Notch-1 pathway activator by a novel high-throughput screening method (167). In human neuroendocrine BON1 and H727 cells in vitro, resveratrol induced functional Notch-2 signalling, decreased ASCL1 protein expression, increased expression levels of p21 and cdc2, induced cell cycle arrest and inhibited tumour cell growth in vitro (167). In addition, resveratrol also suppressed growth of H727 carcinoid tumours in vivo in a mouse tumour xenograft (167). In a current clinical trial (NCT01476592), the biological effects of resveratrol in Notch-1 signalling in patients with low-grade gastrointestinal tumours were analysed.

The marine-derived Notch-1 signalling activator thiodepsipeptide thiocoraline showed Notch-1 downstream target activation and caused cell cycle arrest in BON1 and $\mathrm{H} 727$ cells in vitro (176). Also in a BON1 xenograft model, thiodepsipeptide thiocoraline demonstrated anti-tumoural efficacy (176).

Wnt/beta-catenin The Wnt/beta-catenin signalling pathway has been extensively reviewed by others (136, 176) (Fig. 1).

The Wnt/beta-catenin signalling pathway is aberrantly regulated in many cancers including colorectal adenocarcinoma, resulting in constitutively active beta-catenin signalling (177). Loss of function in APC or Axin and beta-catenin gain of function mutations prevent its phosphorylation and/or degradation and lead to constitutive Wnt/beta-catenin signalling, which is frequent in colorectal cancer and other tumours (177).
In NET tumour samples, cytoplasmic and nuclear beta-catenin accumulation indicating Wnt/beta-catenin signalling activation has been reported in 16\% (1/12 GI carcinoids and $1 / 6$ bronchial carcinoids) (178). In ileal neuroendocrine neoplasms, the APC gene was deleted in $15 \%(4 / 27)$ and somatic mutations of the APC gene were detected in 23\% (7/30) of examined tumour samples, including 57\% missense and 14\% nonsense/frameshift mutations (179). Loss of APC function was not found to be a negative predictive marker in this small cohort (179). Low-grade NETs are sporadically observed in patients with familial adenomatous polyposis; high nuclear levels of beta-catenin give evidence for a possible pathogenic role of the adenomatous polyposis coli/beta-catenin pathway in these NETs (180).

Controversial data contradicting the classical role of Wnt/beta-catenin in tumourigenesis have been reported from an in vitro study with rodent islet tumour cell lines TGP-61 and InR1G9 (181). In this model, menin has been reported to be crucial for canonical Wnt/ beta-catenin signalling and activation of the Wnt/betacatenin signalling pathway to inhibit islet tumour cell proliferation (181). In contrast, menin has been reported to be important for phosphorylation of beta-catenin, and in MEN1-deficient knockout mice, beta-catenin signalling is activated in pancreatic NETs (182). Conditional betacatenin knock out in MEN1-deficient knockout mice decreased tumourigenesis of pancreatic NETs (182).

In human pancreatic carcinoid BON1 cells, in vitro re-expression of the negative regulators of the Wnt/ beta-catenin pathway (e.g., SFRP-1, Axin-2, DKK-1, DKK-3 and WIF-1) was significantly induced by the DNA methyltransferase inhibitor 5-AZA-CdR (178). Transfection of several inhibitors of the Wnt/beta-catenin pathway, e.g., SFRP-1, DKK-1 and WIF-1, in BON1 cells inhibited colony formation by $40-60 \%$ (178). These findings suggest that epigenetic silencing of the Wnt/beta-catenin pathway through upregulation of negative regulators or active inhibition of the Wnt/beta-catenin pathway can cause anti-proliferative effects in BON1 cells (178). In silico analyses of the intestinal hormone neurotensin promoter showed that at least four consensus of TCF-binding elements and a Wnt signal lead to augmented secretion and intracellular accumulation of neurotensin in BON1 and QGP1 cell lines $(183,241)$. While Wnt/beta-catenin pathway activation induces transcriptional expression of neurotensin, the selective Wnt inhibitor iCRT3 decreased neurotensin and cyclin D1 expression levels in BON1 cells (183). On the other hand, neurotensin has been shown to promote BON1 cell growth in vitro, and this indicates 
neurotensin as a direct target of the Wnt/beta-catenin signalling pathway which might function as a pivotal mediator in NET growth (183).

Downregulation of the Wnt inhibitor Dick-kopf-1 (DKK-1) and subsequent Wnt signalling activation promoted tumourigenesis in an NET model in vivo and caused tumour cell survival, proliferation and invasiveness (184).

Pharmacological inhibition of the Wnt/beta-catenin pathway by small-molecule inhibitors as PRI-724, CWP232291, LGK974, Foxy-5 and monoclonal antibodies as OMP-54F28, OMP-18R5 or OTSA 1010 has entered clinical phase 1 studies in oncology $(185,186,187)$. Several other compounds are in preclinical development $(185,186,187)$. Targeting the Wnt/beta-catenin pathway in NETs seems worth to be investigated in preclinical and clinical trials in the future.

TGF-beta signalling and SMAD proteins The TGFbeta superfamily encompasses TGF-beta proteins and bone morphogenetic proteins. TGF-beta signalling is mediated by transforming growth factor-beta receptors 1 and 2 and intracellular SMAD proteins (188).

Gilbert and coworkers demonstrated by IHC analysis a high expression level of transforming growth factor-beta receptor 1 (TGFBR1) with intensity score 3 in $74 \%$ and intensity scores 2 and 3 in almost 100\% of pancreatic NETs (118) and with intensity score 3 in 28\% and intensity scores 2 and 3 in almost 100\% of GI-NETs (189). SMAD genes have been demonstrated to be often mutated or deleted in SI-NETs in approximately 45\% (22/48 tumours) (11).

The putative therapeutic potential of TGF-beta signalling in GEP-NETs is very difficult to predict as TGF-beta signalling has demonstrated discrepant results with tumour growth inhibition as well as tumour growth activation in different preclinical GEP-NET models, as has been extensively reviewed by Kidd and coworkers (190).

\section{Tumour suppressors and the cell cycle}

p53 The TP53 gene encodes p53 an important tumour suppressor transcribing a network of genes including p21 and being implicated in DNA repair, cell growth arrest or cell senescence, apoptosis and autophagy (191, 192). Mutations of the TP53 gene with loss of function concerning its tumour suppressor role as well as reduced functional p53 protein expression because of changes in p53 modulators are existent in many cancers and contribute to malignant progression $(191,192,193)$.
The most recognised modulators of p53 expression are wild-type p53-induced phosphatase 1 (WIP1), murine double minute (MDM2) and murine double minute X (MDMX) (194, 195). The MDM2 gene encodes an E3 ubiquitin ligase that generates the ubiquitination of p53 resulting in its proteasomal degradation $(194,195)$. The WIP1 dephosphorylates and thereby inactivates upstream activators like ATM, CHK1 and CHK2 and p53 itself and stabilises the p53 inhibitor MDM2 by dephosphorylating it at Ser 395 (196). Ataxia telangiectasia mutated kinase (ATM) mediates DNA damage response-induced activation of p53 (197, 198). ATM also regulates together with WIP1 the phosphorylation of DAXX protein (198), while DAXX itself is not involved in p53 expression and p53 downstream signalling (198).

High expression of ATM expression in pancreatic NETs is associated with higher tumour differentiation, lower tumour size, lower recurrence rate and better prognosis (199), while loss of ATM expression is common in metastasized disease and is associated with worse prognosis (200). Loss of p53 and Rb in different mouse models caused development of pancreatic NETs (201, 202). PHLDA3, a target gene of p53, competes with Akt for binding to membrane lipids inhibiting Akt translocation and activation. Loss of PHLDA3 increases Akt activity and decreases p53-dependent apoptosis, revealing the tumoursuppressive role of PHLDA3 and the link between p53 and Akt signalling (203). PHLDA3 has also been shown to be a tumour suppressor in pancreatic NETs (204).

Mutations of the TP53 gene encoding p53 protein are rare in GEP-NETs and have been reported only in 1\% (1/89) (205) to 3\% (13). However, Hu and coworkers (206) observed a high rate of copy number gains of MDM2 in $22 \%$, MDM 4 in $40 \%$ and WIP1 in $51 \%$ of pancreatic NETs. Therefore, inhibition of p53 modulators as MDM2 and induction of re-expression of p53 wild-type in GEP-NETs might be a promising therapeutic strategy (207) and should be investigated. Unfortunately, the majority of available GEP-NET cell lines do not reflect the wild-type TP53 status (208) or have not been assessed so far, making it difficult to estimate possible targets in those cell lines and thus limiting the possibilities for a transferable in vitro drug assessment (209).

Possible therapeutic strategies in oncology to re-induce wild-type p53 expression and function reach from p53 activator stimulation to a possible inhibition of its negative regulators such as MDM2 inhibitors (207, 210), MDM4 inhibitors (211) and WIP1 inhibitors (212). Preliminary data in human NET cell lines in vitro have been reported, demonstrating MDM2 inhibition to be 

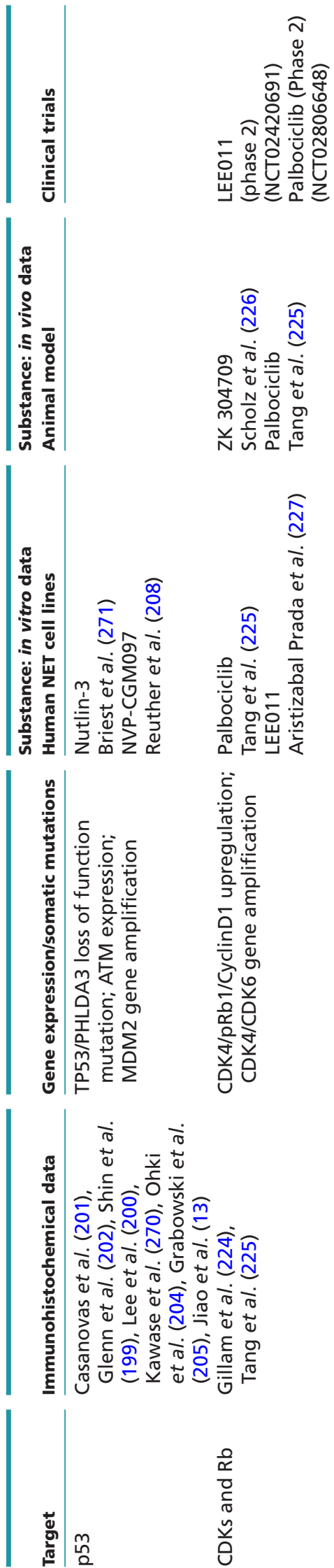

\section{$\frac{0}{x}$
0
$\frac{0}{\pi}$
$\tilde{y}$
$\frac{0}{0}$}

a potential novel target in p53-wild-type NETs. In the human SI-NET cell line KRJ-I, the MDM2 inhibitor nutlin-3 caused upregulation of p21 and inhibition of cell proliferation (209). In the human SI-NET cell line GOT1, the MDM2 inhibitor NVP-CGM097 caused upregulation of p53 and p21 and inhibition of cell proliferation (208). Furthermore, NVP-CGM097 showed additive effects with 5-fluorouracil on cellular survival decrease because of enhanced downregulation of the p53-p21-Rb-E2F1 cascade in the p53 wild-type NET cell line GOT1 (208).

Based on current findings $(198,206,213)$ (Table 4), future preclinical studies should also evaluate the putative correlations of expression patterns of WIP1, ATM and DAXX phosphorylation status in GEP-NETs, as well as the putative role of novel WIP1 inhibitors on P53-p21-Rb activity and DAXX phosphorylation status in GEP-NETs.

CDKs and Rb The family of cyclin-dependent kinases (CDKs) encompasses 20 members (214) which catalyse the phosphorylation of key proteins and transcription factors implicated in cell cycle transition (215).

CyclinC-CDK3, CyclinD-CDK4 and CyclinD-CDK6 regulate in quiescent cells the G0-G1 transition and the early G1 phase in proliferating cells by phosphorylating the tumour suppressor retinoblastoma protein $\mathrm{pRb}$ and thus activating E2F (216) (Fig. 1).

CDKs and their regulators are often misregulated in cancer cells and become unable to accomplish properly their cell cycle, transcription and/or proliferation controlling role $(217,218)$. The CDK4-cyclin D-Rb-E2F cascade is aberrant in many cancers, including GEP-NETs $(214,219,220)$ (Table 4). The oral selective CDK4/6 inhibitor palbociclib (PD0332991) in combination with fulvestrant has been approved as first-in-class drug for the treatment of ER-positive, HER2-negative breast cancer $(214,221,222)$. Other CDK4/6 inhibitors as ribociclib (LEE011) and abemaciclib (LY2835219) are in clinical development $(214,219,220,223)$.

While Men1(+/-) as well as Men1(+/-); Cdk2(-/-) mice develop pituitary and pancreatic NETs, Men1(+/-); Cdk4(-/-) mice do not (224). These data indicate CDK4 to be essential for tumourigenesis of pancreatic NETs (224). In 92 tumour samples of human pancreatic NETs, overexpression of CDK4 and phospho-Rb1 was detected in $58 \%$ and $68 \%$, and the respective expression levels were positively correlated with each other (225). Gene amplifications of CDK4 or CDK6 were found in 19\% (5/26) investigated tumour samples (225). In an orthotopic BON1 xenograft model, the multi-inhibitor ZK 304709

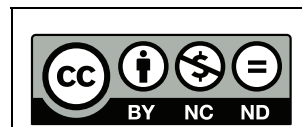

This work is licensed under a Creative Commons Attribution-NonCommercial-NoDerivatives 4.0 International License. 
(CDK1, 2, 4, 7 and 9, VEGFR, PDGFR) caused significant anti-tumoural effects by induction of apoptosis and inhibition of angiogenesis (226). Investigation of CDK gene copy numbers in BON1, H727 and QGP1 human NET cell lines revealed H727 cells to harbour three copies and QGP1 cells to harbour six copies of the CDK4 gene (225). In an orthotopic BON1 xenograft model, the multiinhibitor ZK 304709 (CDK1, 2, 4, 7 and 9, VEGFR, PDGFR) caused significant anti-tumoural effects by induction of apoptosis and inhibition of angiogenesis (226). The CDK4/6 inhibitor Palbociclib (PD0332991) reactivated $\mathrm{Rb} 1$, induced G1 cell cycle arrest and inhibited tumour cell growth in BON1 and QGP1 cells in vitro and also showed anti-tumoural activity in a QGP1 xenograft model in vivo (225). The CDK4/6 inhibitor ribociclib (LEE011) decreased tumour cell proliferation in BON1, QGP1 and H727 cells, through dephosphorylation of $\mathrm{Rb}$ and $\mathrm{a}$ subsequent G1 phase cell cycle arrest in vitro (227). LEE011 was ineffective in GOT1 cells, and treatment sensitivity towards LEE011 was associated with high expression of cyclin D1 and $\mathrm{Rb}$ (227). Combination treatment of LEE011 and 5-fluorouracil or everolimus showed a significant enhancement in the inhibition of cell viability when compared to single-substance treatments because of PI3K-Akt-mTOR and Ras-Raf-MEK-ERK pathway downregulation and cooperative downregulation of cell cycle components (227). However, LEE011 also exhibited antagonising effects with 5-fluorouracil, protecting NET cells from the DNA-damaging effects of chemotherapy (227). Hence, the efficiency of a dual targeting approach with LEE011 and chemotherapeutic agents in NETs remains to be assessed in the clinic (227). Clinical phase 2 trials of Ribociclib (LEE011) (NCT02420691) and Palbociclib (PD0332991) (NCT02806648) in patients with NETs are currently recruiting patients (76).

p27 The CDK inhibitor p27 (also known as KIP1) is encoded by the $C D K N 1 B$ gene and regulates the transition from cell cycle phase G0/G1 to $S$ and is implicated in cellular processes like proliferation, motility and apoptosis (228).

Pellegata and coworkers $(229,230)$ first described mutations in CDKN1B gene causing a p27 deficiency and a new MEN-like phenotype in rats and humans, further on named MEN-4 (MENX) syndrome $(229,230)$. CDKN1B gene mutations in MEN-4 (MENX) syndrome predominantly cause pituitary and parathyroid tumours $(229,230)$.

Exome and genome analyses of SI-NETs identified frameshift mutations in the CDKN1B gene in $8 \%(14 / 180)$ and deletions in $15 \%$ (7/50) (12); thus, the CDKN1B gene constitutes the most commonly mutated gene in SI-NETs (231). Another large cohort study with SI-NET tumour samples also demonstrated mutations in the CDKN1B in $8.5 \%(17 / 200)(232)$. However, neither a correlation between CDKN1B mutation status and p27 protein expression level nor between clinical characteristics of CDKN1B mutated and CDKN1B wild-type tumour patients could be encountered (232). Because of these data, CDKN1B has been suggested a potential haploinsufficient tumour suppressor gene in SI-NETs (232). In 55 MEN1 patients, the single nucleotide polymorphism V109G in the CDKN1B gene was detected in 44\% (24/55) of the patients (233). The SNP V109G CDKN1B gene was significantly correlated with a faster development of aggressive MEN1-related tumours (233). The expression level of p27 turned out to be subtype (WHO class) specific and in combination with Cyclin-E expression, a correlation of low p27 expression and overexpression of cyclin E was found to play a role in the aggressiveness in GEP-NETs (205). In an analysis of 327 GEP-NET tumour samples, loss of p27 protein expression which occurred in $21 \%$ was a predictor of poor overall survival and poor prognosis (234).

Currently, there are no established drugable targets to reactivate or increase p27 expression in cancers, respective GEP-NETs (Table 4). The E3 ubiquitin ligase S-phase kinaseassociated protein 2 (Skp2) is an important mediator of ubiquitination of various proteins including p27, rendering them to subsequent proteasomal degradation. Small-molecule inhibitors of the E3 ubiquitin ligase Skp2 (235) might be a promising future therapeutic approach in cancer $(236,237)$ and then might also be worth to be investigated in GEP-NETs.

\section{Other important pathways}

Hsp90 The heat shock protein 90 (Hsp90) is a highly conserved and essential component of the molecular chaperone family (238). The central function of Hsp90 is the proper folding, maturation and the structural integrity regulation of an enormous subgroup of proteins that are involved in major cellular processes, such as cell cycle regulation, cellular proliferation and apoptosis (238). Heat shock proteins are overexpressed in various cancers, and their overexpression is a negative prognostic indicator of therapeutic resistance and poor survival (239). Hsp90 inhibitors cause misfolding and consequent ubiquitination and proteasomal degradation of client proteins and are currently in clinical development $(238,240)$.

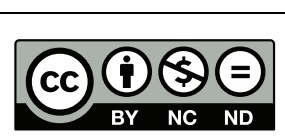

This work is licensed under a Creative Commons Attribution-NonCommercial-NoDerivatives 4.0 International License. 
Gilbert and coworkers demonstrated by IHC analysis a high expression level of Hsp90 with intensity scores 2 and 3 in almost 100\% of pancreatic NETs (118) and with intensity score 3 in $74 \%$ and intensity scores 2 and 3 in almost $100 \%$ of GI-NETs (189). The Hsp90 gene was amplified in $10 \%(5 / 48)$ patients in SI-NETs (11).

In vitro assays with various human NET cell lines showed anti-proliferative effects of several Hsp90 inhibitors as AUY922 (241), HSP990 (241), IPI-504 (242) and 17-(allylamino)-17-demethoxygeldanamycin (17-AAG) $(118,189)$. The Hsp90 inhibitors AUY922 and HSP990 inhibited cell proliferation of human BON1, H727 and GOT1 NET cells and the inhibitory effects were shown to be associated with decreased ErbB and IGF-1 receptor expression as well as decreased Erk and Akt phosphorylation levels (241). The Hsp90 inhibitor IPI-504 inhibited in NET cell proliferation of human BON1 and CM NET cells and inhibited client targets from the PI3K-Akt-mTOR pathway and decreased levels of IGF-1 receptor expression (242). Combination of the Hsp90 inhibitor IPI-504 with mTOR or AKT inhibitors caused synergistic anti-tumoural effects (242). The Hsp90 inhibitor 17-(allylamino)-17demethoxygeldanamycin (17-AAG) significantly blocked proliferation in bronchopulmonary NET cell lines NCI-H727, NCI-H720 and NCI-H835 and in pancreatic NET cell line QGP-1 and induced a loss of EGFR, IGF1R and VEGFR2 $(118,189)$.

Aurora kinase Aurora kinases are serine-threonine kinases playing an important role in the regulation of mitosis and include aurora kinase A (AURKA), auroras kinase B (AURKB) and aurora kinase C (AURKC) (243). Overexpression of either Aurora kinase can lead to tumourigenesis and is evidenced in many human cancers and propose new possible targeting strategies (243).

AURKA regulates several proteins important in carcinogenesis, as for example aurora kinase A inhibits p53 transactivation (244), activates MDM2 and enhances p53 proteasomal degradation (244), inhibits GSK3- $\beta$ and enhances $\beta$-catenin activity, and activates SRC and promotes cancer cell invasion (243).

Aurora kinase inhibitors such as alisertib (MLN8237), danusertib (PHA-739358), MK-5108 (VX689) and ENMD2076 are in clinical development (243).

The AURKA gene has been demonstrated to be often amplified in SI-NETs in approximately 19\% (9/48) (7). AURKA protein expression has been found in 95\% (41/43) of the GEP-NET tumour samples (245).
The aurora kinase inhibitor ZM447439 inhibited cell proliferation of human NET cells BON1, QGP1 and MIP-101 and showed synergistic anti-proliferative effects with streptozocin and cisplatin (246). The aurora kinase inhibitor danusertib (PHA-739358) inhibited cell proliferation of human pancreatic NET cells BON1 and QGP1 in vitro and in a murine orthotopic xenograft model (245).

HDAC HDAC inhibitors are epigenetic modulators (247) and several HDACs such as vorinostat (SAHA), belinostat (PXD101), panobinostat (LBH-589) and romidepsin (FK228 and FR901228) have been licensed (248), while others such as entinostat (SNDX-275) are under clinical development (249). HDAC inhibitors are of great interest for anti-cancer drug development (250).

Epigenetic changes in NETs have recently been extensively reviewed by Karpathos and coworkers (251) including aberrant methylated loci, chromatin remodelling and miRNA expression patterns. Aberrant methylated loci in NETs have been described for DKN2a/ P16INK4a, RASSF1, TIMP3, MGMT, hMLH1, P16, APC, CTNNB1, HIC1, E-cadherin, RAR $\beta$, MEN1, VHL, PTEN, P14, GATA5, ESR1, GST, RUNX3, P14, THBS1, RAR (RARA), P73 (TP73), WT1, CDH13 and CIMP status, respectively (251). Differential epigenetic changes have been shown to be mediated by DAXX or ATRX gene mutations (15) and MEN1 gene mutations $(252,253)$ in NETs.

Based on the role of epigenetic changes in GEP-NETs, treatment with HDAC inhibitors might be promising. Preclinical in vitro models demonstrated dose-dependent inhibition of cell proliferation and induction of apoptosis and cell cycle arrest in GI-NET cell lines CM and BON1 treated with the HDAC inhibitors trichostatin A, sodium butyrate (NaB) and MS-275, respectively (254). VPA is also an HDAC inhibitor and has shown Notch-1 activation and anti-tumoural effects in preclinical NET models (104, 172 , 173) (for review, see the aforementioned chapter on Notch-1 signalling). In addition, VPA has also been demonstrated to increase somatostatin receptor subtype 2 expression in NET cells (255).

In contrast to a mechanistic rationale and promising preclinical results with HDAC inhibitors in NETs, the clinical development in NETs has not been successful so far, as reviewed by Karpathakis and coworkers (251). A clinical phase 2 trial with depsipeptide in NET patients was terminated because of cardiac toxicity (256). Two clinical phase 2 trials with panobinostat (LBH589) in 
low-grade NETs demonstrated only stable disease as the best response with a median PFS of 9.9 months (257). A clinical phase II study in patients with low-grade NETs of the HDAC inhibitor VPA demonstrated only stable as the best response (174). Our increasing knowledge and understanding of the epigenetic modifications in NETs (251) might help us to improve this therapeutic strategy in the future.

Src Src is a proto-oncogene belonging to the Src kinase family (258). Inhibitors of the SRC family of tyrosine kinases (SFK) such as dasatinib, bosutinib or sarcatinib (AZD0530) have been explored in other haematologic and solid tumours (258).

CSCs have been identified as a novel important putative target for medical therapy in the oncological field $(259,260)$, including CSCs from NETs (141, 261, 262). Embryonic pathways such as Src, Hedgehog (136), Notch-1 (136), Wnt-beta-catenin (136) and transforming growth factor- $\beta$ have been suggested to be important players in this field $(141,261,262)$. Human NET CSCs have been identified with the Aldefluor (Stemcell Technologies, Vancouver, Canada) assay as aldehyde dehydrogenasepositive $(\mathrm{ALDH}+)$ cells (262). Sorting the human midgut carcinoid cell line CNDT2.5, CNDT2.5 ALDH+ cells formed in vitro tumour spheres, whereas CNDT2.5 ALDH- cells did not (262). In a xenograft model, CNDT2.5 ALDH+ cells caused more aggressive tumour growth in comparison to CNDT2.5 ALDH- cells (262). Src expression was increased in ALDH+ cells and treatment of ALDH+ tumours with anti-Src short interfering RNA reduced tumour mass by 91\% (262).

In human NETs, Src has been found to be often amplified in approximately 23\% (11/48 tumours) of all SI-NETs investigated (11).

In human neuroendocrine pancreatic QGP1, BON1 and CM cells in vitro, expression levels of activated p-Src (Tyr 416) and activated downstream targets of mTOR, namely p4EBP1 and p-rpS6 correlated positively (263). Treatment of QGP1 and BON1 cells with the SFK inhibitor PP2 or RNAi depletion of endogenous Src deactivated the mTOR pathway downstream targets 4EBP1 and rpS6 indicating an interaction between Src and mTOR signalling in GEP-NETs (263).

These preclinical findings suggest an important role for Src and possibly other members of the Src family of tyrosine kinases (SFK) as possible target in the treatment of GEP-NETs alone or in combination with mTOR inhibitors as has been extensively reviewed by Capurso and coworkers (264).
FAK The non-receptor tyrosine kinase FAK is a scaffolding protein interacting with growth factors and integrins and regulating Src and PI3K-Akt signalling (265). FAK is overexpressed and hyperphosphorylated in pancreatic NETs (59). FAK has also been shown to be involved in cellular adhesion and migration in the BON1 carcinoid cell line in vitro (128). The FAK inhibitor PF-04554878 inhibited pancreatic NET proliferation in an orthotopic xenograft mouse model and showed synergistic antitumoural effects in combination with everolimus (59). Another FAK inhibitor OXA-11 inhibited pancreatic NET liver metastases in the Rip-Tag2 transgenic mice model alone and synergistically together with the anti-VEGFR-2 antibody DC101 (266).

\section{Conclusion}

A number of promising novel molecular targets defined by preclinical and early clinical studies in NETs of the GEP system are discussed in this review in order to provide the translational as well as the clinical researcher with a comprehensive overview of the current status of the field. Combinational treatment approaches with 'dual horizontal targeting' of different signalling pathways or 'dual vertical targeting' of the same pathway at different points in the signalling cascade represent powerful tools to enhance anti-tumour efficacy and to overcome resistance mechanisms. However, dualtargeted therapy in clinical trials has so far often been limited by increased toxicity and side effects. Promising novel molecular targeting approaches to become translated into clinical treatment of NETs of the GEP system in the future might include strategies to target the CDK4/6-Rb-E2F axis or GSK3 signalling, as well as targeted upregulation of the tumour suppressor p53 or epigenetic modulation of various target genes. Future translational research is required to further improve our understanding of tumour biology and to translate preclinical data into clinical treatments strategies in NETs of the GEP system.

\section{Declaration of interest}

C J A has received research contracts (Ipsen, Novartis), lecture honorarium (Ipsen, Novartis, Pfizer, Amgen, Roche, Falk) and advisory board honorarium (Novartis). The authors declare that there is no conflict of interest that would prejudice the impartiality of this scientific work.

Funding

E T Aristizabal Prada has received a scholarship from FAZIT-Stiftung (http:// www.fazit-stiftung.de).

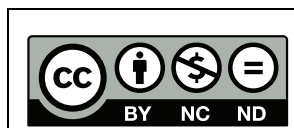

This work is licensed under a Creative Commons Attribution-NonCommercial-NoDerivatives 4.0 International License. 


\section{Acknowledgements}

The authors want to acknowledge G Spöttl and J Maurer for bibliographic editorial assistance. This manuscript was edited for proper English language, grammar, punctuation and spelling by editors of www.proofreading-service.com

\section{References}

1 Frilling A, Modlin IM, Kidd M, Russell C, Breitenstein S, Salem R, Kwekkeboom D, Lau WY, Klersy C, Vilgrain V, et al. Recommendations for management of patients with neuroendocrine liver metastases. Lancet Oncology 201415 e8-e21. (https://doi. org/10.1016/S1470-2045(13)70362-0)

2 Pavel M, O'Toole D, Costa F, Capdevila J, Gross D, Kianmanesh R, Krenning E, Knigge U, Salazar R, Pape UF, et al. ENETS Consensus Guidelines Update for the management of distant metastatic disease of intestinal, pancreatic, bronchial neuroendocrine neoplasms (NEN) and NEN of unknown primary site. Neuroendocrinology 2016103 172-185. (https://doi.org/10.1159/000443167)

3 Auernhammer CJ \& Goke B. Therapeutic strategies for advanced neuroendocrine carcinomas of jejunum/ileum and pancreatic origin. Gut 201160 1009-1021. (https://doi.org/10.1136/ gut.2009.204453)

4 Garcia-Carbonero R, Sorbye H, Baudin E, Raymond E, Wiedenmann B, Niederle B, Sedlackova E, Toumpanakis C, Anlauf M, Cwikla JB, et al. ENETS Consensus Guidelines for high-grade gastroenteropancreatic neuroendocrine tumours and neuroendocrine carcinomas. Neuroendocrinology 2016103 186-194. (https://doi. org/10.1159/000443172)

5 Pavel M, Valle JW, Eriksson B, Rinke A, Caplin M, Chen J, Costa F, Falkerby J, Fazio N, Gorbounova V, et al. ENETS Consensus Guidelines for the standards of care in neuroendocrine neoplasms: systemic therapy - biotherapy and novel targeted agents. Neuroendocrinology 2017105 266-280.

6 Garcia-Carbonero R, Rinke A, Valle JW, Fazio N, Caplin M, Gorbounova V, O'Connor J, Eriksson B, Sorbye H, Kulke M, et al. ENETS Consensus Guidelines for the standards of care in neuroendocrine neoplasms. systemic therapy 2: chemotherapy. Neuroendocrinology 2017105 281-294.

7 Strosberg JR, Halfdanarson TR, Bellizzi AM, Chan JA, Dillon JS, Heaney AP, Kunz PL, O'Dorisio TM, Salem R, Segelov E, et al. The North American Neuroendocrine Tumour Society Consensus Guidelines for surveillance and medical management of midgut neuroendocrine tumours. Pancreas 201746 707-714. (https://doi. org/10.1097/MPA.0000000000000850)

8 Hicks RJ, Kwekkeboom DJ, Krenning E, Bodei L, GrozinskyGlasberg S, Arnold R, Borbath I, Cwikla J, Toumpanakis C, Kaltsas G, et al. ENETS Consensus Guidelines for the standards of care in neuroendocrine neoplasia: peptide receptor radionuclide therapy with radiolabeled somatostatin analogues. Neuroendocrinology 2017 105 295-309.

9 Walenkamp A, Crespo G, Fierro Maya F, Fossmark R, Igaz P, Rinke A, Tamagno G, Vitale G, Oberg K \& Meyer T. Hallmarks of gastrointestinal neuroendocrine tumours: implications for treatment. Endocrine-Related Cancer 201421 R445-R460. (https://doi. org/10.1530/ERC-14-0106)

10 Kidd M, Drozdov I \& Modlin I. Blood and tissue neuroendocrine tumour gene cluster analysis correlate, define hallmarks and predict disease status. Endocrine-Related Cancer 201522 561-575. (https://doi. org/10.1530/ERC-15-0092)

11 Banck MS, Kanwar R, Kulkarni AA, Boora GK, Metge F, Kipp BR, Zhang L, Thorland EC, Minn KT, Tentu R, et al. The genomic landscape of small intestine neuroendocrine tumours. Journal of
Clinical Investigation 2013123 2502-2508. (https://doi.org/10.1172/ JCI67963)

12 Francis JM, Kiezun A, Ramos AH, Serra S, Pedamallu CS, Qian ZR, Banck MS, Kanwar R, Kulkarni AA, Karpathakis A, et al. Somatic mutation of CDKN1B in small intestine neuroendocrine tumours. Nature Genetics 201345 1483-1486. (https://doi.org/10.1038/ ng.2821)

13 Jiao Y, Shi C, Edil BH, de Wilde RF, Klimstra DS, Maitra A, Schulick RD, Tang LH, Wolfgang CL, Choti MA, et al. DAXX/ATRX, MEN1, and mTOR pathway genes are frequently altered in pancreatic neuroendocrine tumours. Science 2011331 1199-1203. (https://doi. org/10.1126/science.1200609)

14 Rodriguez-Rodero S, Delgado-Alvarez E, Fernandez AF, FernandezMorera JL, Menendez-Torre E \& Fraga MF. Epigenetic alterations in endocrine-related cancer. Endocrine-Related Cancer 201421 R319-R330. (https://doi.org/10.1530/ERC-13-0070)

15 Pipinikas CP, Dibra H, Karpathakis A, Feber A, Novelli M, Oukrif D, Fusai G, Valente R, Caplin M, Meyer T, et al. Epigenetic dysregulation and poorer prognosis in DAXX-deficient pancreatic neuroendocrine tumours. Endocrine-Related Cancer 201522 L13-L18. (https://doi. org/10.1530/ERC-15-0108)

16 Oberg K, Casanovas O, Castano JP, Chung D, Delle Fave G, Denefle P, Harris P, Khan MS, Kulke MH, Scarpa A, et al. Molecular pathogenesis of neuroendocrine tumours: implications for current and future therapeutic approaches. Clinical Cancer Research 201319 2842-2849. (https://doi.org/10.1158/1078-0432.CCR-12-3458)

17 Raymond E, Garcia-Carbonero R, Wiedenmann B, Grande E \& Pavel M. Systemic therapeutic strategies for GEP-NETS: what can we expect in the future? Cancer Metastasis Reviews 201433 367-372. (https://doi.org/10.1007/s10555-013-9467-z)

18 Cella CA, Minucci S, Spada F, Galdy S, Elgendy M, Ravenda PS, Zampino MG, Murgioni S, Fazio N: Dual inhibition of mTOR pathway and VEGF signalling in neuroendocrine neoplasms: from bench to bedside. Cancer Treatment Reviews 201541 754-760. (https://doi.org/10.1016/j.ctrv.2015.06.008)

19 Kloppel G. Classification and pathology of gastroenteropancreatic neuroendocrine neoplasms. Endocrine-Related Cancer 201118 (Supplement 1) S1-S16. (https://doi.org/10.1530/ERC-11-0013)

20 Rindi G, Petrone G \& Inzani F. 25 years of neuroendocrine neoplasms of the gastrointestinal tract. Endocrine Pathology 201425 59-64. (https://doi.org/10.1007/s12022-013-9292-5)

21 Cakir M \& Grossman A. The molecular pathogenesis and management of bronchial carcinoids. Expert Opinion on Therapeutic Targets 201115 457-491. (https://doi.org/10.1517/14728222.2011.55 5403)

22 Grozinsky-Glasberg S, Shimon I \& Rubinfeld H. The role of cell lines in the study of neuroendocrine tumours. Neuroendocrinology 201296 173-187. (https://doi.org/10.1159/000338793)

23 Babu V, Paul N \& Yu R. Animal models and cell lines of pancreatic neuroendocrine tumours. Pancreas 201342 912-923. (https://doi. org/10.1097/MPA.0b013e31827ae993)

$24 \mathrm{Yu}$ R. Animal models of spontaneous pancreatic neuroendocrine tumours. Molecular and Cellular Endocrinology 2016421 60-67. (https://doi.org/10.1016/j.mce.2015.08.004)

25 Evers BM, Townsend CM Jr, Upp JR, Allen E, Hurlbut SC, Kim SW, Rajaraman S, Singh P, Reubi JC \& Thompson JC. Establishment and characterization of a human carcinoid in nude mice and effect of various agents on tumour growth. Gastroenterology $1991 \mathbf{1 0 1}$ 303-311. (https://doi.org/10.1016/0016-5085(91)90004-5)

26 Kaku M, Nishiyama T, Yagawa K \& Abe M. Establishment of a carcinoembryonic antigen-producing cell line from human pancreatic carcinoma. Gann 198071 596-601.

27 Kolby L, Bernhardt P, Ahlman H, Wangberg B, Johanson V, Wigander A, Forssell-Aronsson E, Karlsson S, Ahren B, Stenman G, et al. A transplantable human carcinoid as model for somatostatin http://www.endocrineconnections.org

https://doi.org/10.1530/EC-17-0286 (c) 2018 The authors Published by Bioscientifica Ltd
This work is licensed under a Creative Commons Attribution-NonCommercial-NoDerivatives 4.0 International License. 
receptor-mediated and amine transporter-mediated radionuclide uptake. American Journal of Pathology 2001158 745-755. (https://doi. org/10.1016/S0002-9440(10)64017-5)

28 Pfragner R, Wirnsberger G, Niederle B, Behmel A, Rinner I, Mandl A, Wawrina F, Luo J, Adamiker D, Hoger H, et al. Establishment of a continuous cell line from a human carcinoid of the small intestine (KRJ-I). International Journal of Oncology 19968 513-520.

29 Gragnoli C. The CM cell line derived from liver metastasis of malignant human insulinoma is not a valid beta cell model for in vitro studies. Journal of Cellular Physiology 2008216 569-570. (https://doi.org/10.1002/jcp.21453)

30 Pfragner R, Behmel A, Hoger H, Beham A, Ingolic E, Stelzer I, Svejda B, Moser VA, Obenauf AC, Siegl V, et al. Establishment and characterization of three novel cell lines - P-STS, L-STS, H-STS derived from a human metastatic midgut carcinoid. Anticancer Research 200929 1951-1961.

31 Krieg A, Mersch S, Boeck I, Dizdar L, Weihe E, Hilal Z, Krausch M, Mohlendick B, Topp SA, Piekorz RP, et al. New model for gastroenteropancreatic large-cell neuroendocrine carcinoma: establishment of two clinically relevant cell lines. PLOS ONE 20149 e88713. (https://doi.org/10.1371/journal.pone.0088713)

32 Yamada T, Onda M \& Tanaka N. Establishment and characterization of a human rectal neuroendocrine cell carcinoma in vitro. Journal of Experimental and Clinical Cancer Research 200120 561-567.

33 Boora GK, Kanwar R, Kulkarni AA, Pleticha J, Ames M, Schroth G, Beutler AS \& Banck MS. Exome-level comparison of primary well-differentiated neuroendocrine tumours and their cell lines. Cancer Genetics 2015208 374-381. (https://doi.org/10.1016/j. cancergen.2015.04.002)

34 Vandamme T, Peeters M, Dogan F, Pauwels P, Van Assche E, Beyens M, Mortier G, Vandeweyer G, de Herder W, Van Camp G, et al. Wholeexome characterization of pancreatic neuroendocrine tumour cell lines BON-1 and QGP-1. Journal of Molecular Endocrinology 201554 137-147. (https://doi.org/10.1530/JME-14-0304)

35 Wolin EM. PI3K/Akt/mTOR pathway inhibitors in the therapy of pancreatic neuroendocrine tumours. Cancer Letters 2013335 1-8. (https://doi.org/10.1016/j.canlet.2013.02.016)

36 Pavel M. Translation of molecular pathways into clinical trials of neuroendocrine tumours. Neuroendocrinology 201397 99-112. (https://doi.org/10.1159/000336089)

37 Carter Y, Jaskula-Sztul R, Chen H \& Mazeh H. Signaling pathways as specific pharmacologic targets for neuroendocrine tumour therapy: RET, PI3K, MEK, growth factors, and Notch. Neuroendocrinology 2013 97 57-66. (https://doi.org/10.1159/000335136)

38 Wiedenmann B, Pavel M \& Kos-Kudla B. From targets to treatments: a review of molecular targets in pancreatic neuroendocrine tumours. Neuroendocrinology 201194 177-190. (https://doi. org/10.1159/000329386)

39 Toulany M \& Rodemann HP. Phosphatidylinositol 3-kinase/ Akt signaling as a key mediator of tumour cell responsiveness to radiation. Seminars in Cancer Biology 201535 180-190. (https://doi. org/10.1016/j.semcancer.2015.07.003)

40 Pitt SC, Davis R, Kunnimalaiyaan M \& Chen H. AKT and PTEN expression in human gastrointestinal carcinoid tumours. American Journal of Translational Research 20091 291-299.

41 Missiaglia E, Dalai I, Barbi S, Beghelli S, Falconi M, della Peruta M, Piemonti L, Capurso G, Di Florio A, delle Fave G, et al. Pancreatic endocrine tumours: expression profiling evidences a role for AKTmTOR pathway. Journal of Clinical Oncology 201028 245-255. (https://doi.org/10.1200/JCO.2008.21.5988)

42 Cingarlini S, Bonomi M, Corbo V, Scarpa A \& Tortora G. Profiling mTOR pathway in neuroendocrine tumours. Targeted Oncology 2012 7 183-188. (https://doi.org/10.1007/s11523-012-0226-9)

43 Tan HL, Sood A, Rahimi HA, Wang W, Gupta N, Hicks J, Mosier S, Gocke CD, Epstein JI, Netto GJ, et al. Rb loss is characteristic of prostatic small cell neuroendocrine carcinoma. Clinical Cancer Research 201420 890-903. (https://doi.org/10.1158/1078-0432.CCR13-1982)

44 Kasajima A, Pavel M, Darb-Esfahani S, Noske A, Stenzinger A, Sasano H, Dietel M, Denkert C, Rocken C, Wiedenmann B, et al. mTOR expression and activity patterns in gastroenteropancreatic neuroendocrine tumours. Endocrine-Related Cancer 201118 181-192. (https://doi.org/10.1677/ERC-10-0126)

45 Qian ZR, Ter-Minassian M, Chan JA, Imamura Y, Hooshmand SM, Kuchiba A, Morikawa T, Brais LK, Daskalova A, Heafield R, et al. Prognostic significance of MTOR pathway component expression in neuroendocrine tumours. Journal of Clinical Oncology 201331 3418-3425. (https://doi.org/10.1200/JCO.2012.46.6946)

46 Geis C, Fendrich V, Rexin P, Di Fazio P, Bartsch DK, Ocker M, Quint K $\&$ Heverhagen AE. Ileal neuroendocrine tumours show elevated activation of mammalian target of rapamycin complex. Journal of Surgical Research 2015194 388-393. (https://doi.org/10.1016/j. jss.2014.10.052)

47 Yao JC, Shah MH, Ito T, Bohas CL, Wolin EM, Van Cutsem E, Hobday TJ, Okusaka T, Capdevila J, de Vries EG, et al. Everolimus for advanced pancreatic neuroendocrine tumours. New England Journal of Medicine 2011364 514-523. (https://doi.org/10.1056/ NEJMoa1009290)

48 Pavel ME, Hainsworth JD, Baudin E, Peeters M, Horsch D, Winkler RE, Klimovsky J, Lebwohl D, Jehl V, Wolin EM, et al. Everolimus plus octreotide long-acting repeatable for the treatment of advanced neuroendocrine tumours associated with carcinoid syndrome (RADIANT-2): a randomised, placebo-controlled, phase 3 study. Lancet 2011378 2005-2012. (https://doi.org/10.1016/S01406736(11)61742-X)

49 Yao JC, Fazio N, Singh S, Buzzoni R, Carnaghi C, Wolin E, Tomasek J, Raderer M, Lahner H, Voi M, et al. Everolimus for the treatment of advanced, non-functional neuroendocrine tumours of the lung or gastrointestinal tract (RADIANT-4): a randomised, placebocontrolled, phase 3 study. Lancet 2016387 968-977. (https://doi. org/10.1016/S0140-6736(15)00817-X)

50 Meric-Bernstam F, Akcakanat A, Chen H, Do KA, Sangai T, Adkins F, Gonzalez-Angulo AM, Rashid A, Crosby K, Dong M, et al. PIK3CA/ PTEN mutations and Akt activation as markers of sensitivity to allosteric mTOR inhibitors. Clinical Cancer Research 201218 1777-1789. (https://doi.org/10.1158/1078-0432.CCR-11-2123)

51 Gagliano T, Bellio M, Gentilin E, Mole D, Tagliati F, Schiavon M, Cavallesco NG, Andriolo LG, Ambrosio MR, Rea F, et al. mTOR, p70S6K, AKT, and ERK1/2 levels predict sensitivity to mTOR and $\mathrm{PI} 3 \mathrm{~K} / \mathrm{mTOR}$ inhibitors in human bronchial carcinoids. EndocrineRelated Cancer 201320 463-475. (https://doi.org/10.1530/ERC-130042)

52 Duran I, Kortmansky J, Singh D, Hirte H, Kocha W, Goss G, Le L, Oza A, Nicklee T, Ho J, et al. A phase II clinical and pharmacodynamic study of temsirolimus in advanced neuroendocrine carcinomas. British Journal of Cancer 200695 1148-1154. (https://doi.org/10.1038/sj.bjc.6603419)

53 Capozzi M, Caterina I, De Divitiis C, von Arx C, Maiolino P, Tatangelo F, Cavalcanti E, Di Girolamo E, Iaffaioli RV, Scala S, et al. Everolimus and pancreatic neuroendocrine tumours (PNETs): Activity, resistance and how to overcome it. International Journal of Surgery 201521 (Supplement 1) S89-S94. (https://doi.org/10.1016/j. ijsu.2015.06.064)

54 Tijeras-Raballand A, Neuzillet C, Couvelard A, Serova M, de Gramont A, Hammel P, Raymond E \& Faivre S. Resistance to targeted therapies in pancreatic neuroendocrine tumours (PNETs): molecular basis, preclinical data, and counteracting strategies. Targeted Oncology 20127 173-181. (https://doi.org/10.1007/s11523-012-0229-6)

55 Svejda B, Kidd M, Kazberouk A, Lawrence B, Pfragner R \& Modlin IM. Limitations in small intestinal neuroendocrine tumour therapy by http://www.endocrineconnections.org https://doi.org/10.1530/EC-17-0286
() 2018 The authors Published by Bioscientifica Ltd
This work is licensed under a Creative Commons Attribution-NonCommercial-NoDerivatives 4.0 International License. 
mTor kinase inhibition reflect growth factor-mediated PI3K feedback loop activation via ERK1/2 and AKT. Cancer 2011117 4141-4154. (https://doi.org/10.1002/cncr.26011)

56 Zitzmann K, Ruden J, Brand S, Goke B, Lichtl J, Spottl G \& Auernhammer CJ. Compensatory activation of Akt in response to mTOR and Raf inhibitors - a rationale for dual-targeted therapy approaches in neuroendocrine tumour disease. Cancer Letters 2010 295 100-109. (https://doi.org/10.1016/j.canlet.2010.02.018)

57 Iida S, Miki Y, Ono K, Akahira J, Nakamura Y, Suzuki T \& Sasano H. Synergistic anti-tumour effects of RAD001 with MEK inhibitors in neuroendocrine tumours: a potential mechanism of therapeutic limitation of mTOR inhibitor. Molecular and Cellular Endocrinology 2012350 99-106. (https://doi.org/10.1016/j.mce.2011.11.024)

58 Passacantilli I, Capurso G, Archibugi L, Calabretta S, Caldarola S, Loreni F, Delle Fave G \& Sette C. Combined therapy with RAD001 e BEZ235 overcomes resistance of PET immortalized cell lines to mTOR inhibition. Oncotarget 20145 5381-5391. (https://doi.org/10.18632/ oncotarget.2111)

59 Francois RA, Maeng K, Nawab A, Kaye FJ, Hochwald SN \& ZajacKaye M. Targeting focal adhesion kinase and resistance to mTOR inhibition in pancreatic neuroendocrine tumours. Journal of the National Cancer Institute $2015 \mathbf{1 0 7}$ djv123.

60 Fazio N. Neuroendocrine tumours resistant to mammalian target of rapamycin inhibitors: a difficult conversion from biology to the clinic. World Journal of Clinical Oncology 20156 194-197. (https://doi. org/10.5306/wjco.v6.i6.194)

61 Bago-Horvath Z, Sieghart W, Grusch M, Lackner A, Hayden H, Pirker C, Komina O, Wesierska-Gadek J, Haitel A, Filipits M, et al. Synergistic effects of erlotinib and everolimus on bronchia carcinoids and large-cell neuroendocrine carcinomas with activated EGFR/AKT/mTOR pathway. Neuroendocrinology 201296 228-237. (https://doi.org/10.1159/000337257)

62 Capurso G, Fendrich V, Rinzivillo M, Panzuto F, Bartsch DK \& Delle Fave G. Novel molecular targets for the treatment of gastroenteropancreatic endocrine tumours: answers and unsolved problems. International Journal of Molecular Sciences 201214 30-45. (https://doi.org/10.3390/ijms14010030)

63 Moschetta M, Reale A, Marasco C, Vacca A \& Carratu MR. Therapeutic targeting of the mTOR-signalling pathway in cancer: benefits and limitations. British Journal of Pharmacology 2014171 3801-3813. (https://doi.org/10.1111/bph.12749)

$64 \mathrm{Xu} \mathrm{K}$, Liu P \& Wei W. mTOR signaling in tumourigenesis. Biochimica et Biophysica Acta 20141846 638-654

65 Briest F \& Grabowski P. PI3K-AKT-mTOR-signaling and beyond: the complex network in gastroenteropancreatic neuroendocrine neoplasms. Theranostics 20144 336-365. (https://doi.org/10.7150/ thno.7851)

66 Moreno A, Akcakanat A, Munsell MF, Soni A, Yao JC \& MericBernstam F. Antitumour activity of rapamycin and octreotide as single agents or in combination in neuroendocrine tumours. Endocrine-Related Cancer 200815 257-266. (https://doi.org/10.1677/ ERC-07-0202)

67 Spampatti M, Vlotides G, Spottl G, Maurer J, Goke B \& Auernhammer CJ. Aspirin inhibits cell viability and mTOR downstream signaling in gastroenteropancreatic and bronchopulmonary neuroendocrine tumour cells. World Journal of Gastroenterology 201420 10038-10049. (https://doi.org/10.3748/wjg. v20.i29.10038)

68 Grozinsky-Glasberg S, Franchi G, Teng M, Leontiou CA, Ribeiro de Oliveira A Jr Dalino P, Salahuddin N, Korbonits M \& Grossman AB. Octreotide and the mTOR inhibitor RAD001 (everolimus) block proliferation and interact with the Akt-mTOR-p70S6K pathway in a neuro-endocrine tumour cell Line. Neuroendocrinology $2008 \mathbf{8 7}$ 168-181. (https://doi.org/10.1159/000111501)
69 Zitzmann K, De Toni EN, Brand S, Goke B, Meinecke J, Spottl G, Meyer HH \& Auernhammer CJ. The novel mTOR inhibitor RAD001 (everolimus) induces antiproliferative effects in human pancreatic neuroendocrine tumour cells. Neuroendocrinology 200785 54-60. (https://doi.org/10.1159/000100057)

70 Djukom C, Porro LJ, Mrazek A, Townsend CM Jr, Hellmich MR \& Chao C. Dual inhibition of PI3K and mTOR signaling pathways decreases human pancreatic neuroendocrine tumour metastatic progression. Pancreas 201443 88-92. (https://doi.org/10.1097/ MPA.0b013e3182a44ab4)

71 Couderc C, Poncet G, Villaume K, Blanc M, Gadot N, Walter T, Lepinasse F, Hervieu V, Cordier-Bussat M, Scoazec JY, et al. Targeting the PI3K/mTOR pathway in murine endocrine cell lines: in vitro and in vivo effects on tumour cell growth. American Journal of Pathology 2011178 336-344. (https://doi.org/10.1016/j.ajpath.2010.11.023)

72 Soler A, Figueiredo AM, Castel P, Martin L, Monelli E, AnguloUrarte A, Mila-Guasch M, Vinals F, Baselga J, Casanovas O, et al. Therapeutic benefit of selective inhibition of p110alpha PI3-kinase in pancreatic neuroendocrine tumours. Clinical Cancer Research 201622 5805-5817. (https://doi.org/10.1158/1078-0432.CCR-15-3051)

73 Valentino JD, Li J, Zaytseva YY, Mustain WC, Elliott VA, Kim JT, Harris JW, Campbell K, Weiss H, Wang C, et al. Cotargeting the PI3K and RAS pathways for the treatment of neuroendocrine tumours. Clinical Cancer Research 201420 1212-1222. (https://doi. org/10.1158/1078-0432.CCR-13-1897)

74 Nolting S, Rentsch J, Freitag H, Detjen K, Briest F, Mobs M, Weissmann V, Siegmund B, Auernhammer CJ, Aristizabal Prada ET, et al. The selective PI3Kalpha inhibitor BYL719 as a novel therapeutic option for neuroendocrine tumours: results from multiple cell line models. PLoS ONE 201712 e0182852. (https://doi.org/10.1371/ journal.pone.0182852)

75 Antonuzzo L, Del Re M, Barucca V, Spada F, Meoni G, Restante G, Danesi R, Di Costanzo F \& Fazio N. Critical focus on mechanisms of resistance and toxicity of m-TOR inhibitors in pancreatic neuroendocrine tumours. Cancer Treatment Reviews 201757 28-35. (https://doi.org/10.1016/j.ctrv.2017.05.001)

76 Pavel ME \& Sers C. WOMEN IN CANCER THEMATIC REVIEW: Systemic therapies in neuroendocrine tumours and novel approaches toward personalized medicine. Endocrine-Related Cancer 201623 T135-T154. (https://doi.org/10.1530/ERC-16-0370)

77 Yap TA, Bjerke L, Clarke PA \& Workman P. Drugging PI3K in cancer: refining targets and therapeutic strategies. Current Opinion in Pharmacology 201523 98-107. (https://doi.org/10.1016/j. coph.2015.05.016)

78 Zitzmann K, Vlotides G, Brand S, Lahm H, Spottl G, Goke B \& Auernhammer CJ. Perifosine-mediated Akt inhibition in neuroendocrine tumour cells: role of specific Akt isoforms. EndocrineRelated Cancer 201219 423-434. (https://doi.org/10.1530/ERC-120074)

79 Somnay Y, Simon K, Harrison AD, Kunnimalaiyaan S, Chen H \& Kunnimalaiyaan M. Neuroendocrine phenotype alteration and growth suppression through apoptosis by MK-2206, an allosteric inhibitor of AKT, in carcinoid cell lines in vitro. Anti-Cancer Drugs 201324 66-72. (https://doi.org/10.1097/CAD.0b013e3283584f75)

80 Yap TA, Yan L, Patnaik A, Fearen I, Olmos D, Papadopoulos K, Baird RD, Delgado L, Taylor A, Lupinacci L, et al. First-in-man clinical trial of the oral pan-AKT inhibitor MK-2206 in patients with advanced solid tumours. Journal of Clinical Oncology 201129 4688-4695. (https://doi.org/10.1200/JCO.2011.35.5263)

81 Reidy-Lagunes DL, Vakiani E, Segal MF, Hollywood EM, Tang LH, Solit DB, Pietanza MC, Capanu M \& Saltz LB. A phase 2 study of the insulin-like growth factor-1 receptor inhibitor MK-0646 in patients with metastatic, well-differentiated neuroendocrine tumours. Cancer 2012118 4795-4800. (https://doi.org/10.1002/cncr.27459) http://www.endocrineconnections.org

https://doi.org/10.1530/EC-17-0286
() 2018 The authors Published by Bioscientifica Ltd
This work is licensed under a Creative Commons Attribution-NonCommercial-NoDerivatives 4.0 International License. 
82 Gloesenkamp CR, Nitzsche B, Ocker M, Di Fazio P, Quint K, Hoffmann B, Scherubl H \& Hopfner M. AKT inhibition by triciribine alone or as combination therapy for growth control of gastroenteropancreatic neuroendocrine tumours. International Journal of Oncology 201240 876-888.

83 Mita MM, Wolin EM, Meyer T, Nemunaitis JJ, Bergsland EK, Mahipal A, Wong L, Wu X, Carmichael J, Chopra R, et al. Phase I expansion trial of an oral TORC1/TORC2 inhibitor (CC-223) in nonpancreatic neuroendocrine tumours (NET). Journal of Clinical Oncology 201331 e15004-e15004.

84 Freitag H, Christen F, Lewens F, Grass I, Briest F, Iwaszkiewicz S, Siegmund B \& Grabowski P. Inhibition of mTOR's catalytic site by PKI-587 is a promising therapeutic option for gastroenteropancreatic neuroendocrine tumour disease. Neuroendocrinology 2017105 90-104. (https://doi.org/10.1159/000448843)

85 Chiu CW, Nozawa H \& Hanahan D. Survival benefit with proapoptotic molecular and pathologic responses from dual targeting of mammalian target of rapamycin and epidermal growth factor receptor in a preclinical model of pancreatic neuroendocrine carcinogenesis. Journal of Clinical Oncology 201028 4425-4433. (https://doi.org/10.1200/JCO.2010.28.0198)

86 Mohamed A, Romano D, Saveanu A, Roche C, Albertelli M, Barbieri F, Brue T, Niccoli P, Delpero JR, Garcia S, et al. Anti-proliferative and anti-secretory effects of everolimus on human pancreatic neuroendocrine tumours primary cultures: is there any benefit from combination with somatostatin analogs? Oncotarget 20178 41044-41063.

87 Zitzmann K, Andersen S, Vlotides G, Spottl G, Zhang S, Datta R, Culler M, Goke B \& Auernhammer CJ. The novel somatostatin receptor 2/dopamine type 2 receptor chimeric compound BIM-23A758 decreases the viability of human GOT1 midgut carcinoid cells. Neuroendocrinology 201398 128-136. (https://doi. org/10.1159/000353784)

88 Arkwright RT, Deshmukh R, Adapa N, Stevens R, Zonder E, Zhang Z, Farshi P, Ahmed RS, El-Banna HA, Chan TH, et al. Lessons from nature: sources and strategies for developing AMPK activators for cancer chemotherapeutics. Anti-Cancer Agents in Medicinal Chemistry 201515 657-671. (https://doi.org/10.2174/1871520615666141216145417)

89 Larsson O, Morita M, Topisirovic I, Alain T, Blouin MJ, Pollak M \& Sonenberg N. Distinct perturbation of the translatome by the antidiabetic drug metformin. PNAS 2012109 8977-8982. (https:// doi.org/10.1073/pnas.1201689109)

90 Burney S, Khawaja KI, Saif MW \& Masud F. Chemotherapy and metformin in pancreatic adenocarcinoma and neuroendocrine tumours. Journal of the Pancreas 201415 313-316.

91 Miranda VC, Barroso-Sousa R, Glasberg J \& Riechelmann RP. Exploring the role of metformin in anticancer treatments: a systematic review. Drugs of Today 201450 623-640. (https://doi. org/10.1358/dot.2014.50.9.2229920)

92 Din FV, Valanciute A, Houde VP, Zibrova D, Green KA, Sakamoto K, Alessi DR \& Dunlop MG. Aspirin inhibits mTOR signaling, activates AMP-activated protein kinase, and induces autophagy in colorectal cancer cells. Gastroenterology 2012142 1504.e1503-1515.e1503. (https://doi.org/10.1053/j.gastro.2012.02.050)

93 Chen S, Zhu X, Lai X, Xiao T, Wen A \& Zhang J. Combined cancer therapy with non-conventional drugs: all roads lead to AMPK. Mini Reviews in Medicinal Chemistry 201414 642-654. (https://doi.org/10.2 174/1389557514666140820104444)

94 Fendrich V, Lopez CL, Manoharan J, Maschuw K, Wichmann S, Baier A, Holler JP, Ramaswamy A, Bartsch DK \& Waldmann J. Enalapril and ASS inhibit tumour growth in a transgenic mouse model of islet cell tumours. Endocrine-Related Cancer 201421 813-824. (https://doi.org/10.1530/ERC-14-0175)

95 Rinzivillo M, Capurso G, Campana D, Fazio N, Panzuto F, Spada F, Cicchese N, Partelli S, Tomassetti P, Falconi M, et al. Risk and protective factors for small intestine neuroendocrine tumours: a prospective case-control study. Neuroendocrinology 2016103 531-537. (https://doi.org/10.1159/000440884)

96 Vlotides G, Tanyeri A, Spampatti M, Zitzmann K, Chourdakis M, Spttl C, Maurer J, Nolting S, Goke B \& Auernhammer CJ. Anticancer effects of metformin on neuroendocrine tumour cells in vitro. Hormones 201413 498-508.

97 Pusceddu S, de Braud F, Concas L, Bregant C, Leuzzi L, Formisano B \& Buzzoni R. Rationale and protocol of the MetNET-1 trial, a prospective, single center, phase II study to evaluate the activity and safety of everolimus in combination with octreotide LAR and metformin in patients with advanced pancreatic neuroendocrine tumours. Tumouri 2014100 e286-e289.

98 Pusceddu S, Prinzi N, Lo Russo G, Femia D, Milione M, Perrone F, Tamborini E, Concas L, Pulice I, Vernieri C, et al. Rationale and protocol of MetNET-2 trial: Lanreotide Autogel plus metformin in advanced gastrointestinal or lung neuroendocrine tumours. Future Oncology 201713 1677-1683.

99 McCubrey JA, Steelman LS, Bertrand FE, Davis NM, Sokolosky M, Abrams SL, Montalto G, D'Assoro AB, Libra M, Nicoletti F, et al. GSK-3 as potential target for therapeutic intervention in cancer. Oncotarget 20145 2881-2911. (https://doi.org/10.18632/ oncotarget.2037)

100 Wada A. GSK-3 inhibitors and insulin receptor signaling in health, disease, and therapeutics. Frontiers in Bioscience 200914 1558-1570. (https://doi.org/10.2741/3324)

101 Mussmann R, Geese M, Harder F, Kegel S, Andag U, Lomow A, Burk U, Onichtchouk D, Dohrmann C \& Austen M. Inhibition of GSK3 promotes replication and survival of pancreatic beta cells. Journal of Biological Chemistry 2007282 12030-12037. (https://doi. org/10.1074/jbc.M609637200)

102 Greenblatt DY, Ndiaye M, Chen H \& Kunnimalaiyaan M. Lithium inhibits carcinoid cell growth in vitro. American Journal of Translational Research 20102 248-253.

103 Lubner SJ, Kunnimalaiyaan M, Holen KD, Ning L, Ndiaye M, Loconte NK, Mulkerin DL, Schelman WR \& Chen H. A preclinical and clinical study of lithium in low-grade neuroendocrine tumours. Oncologist 201116 452-457. (https://doi.org/10.1634/ theoncologist.2010-0323)

104 Adler JT, Hottinger DG, Kunnimalaiyaan M \& Chen H. Combination therapy with histone deacetylase inhibitors and lithium chloride: a novel treatment for carcinoid tumours. Annals of Surgical Oncology 200916 481-486. (https://doi.org/10.1245/s10434-008-0194-6)

105 Desai SS, Modali SD, Parekh VI, Kebebew E \& Agarwal SK. GSK-3beta protein phosphorylates and stabilizes HLXB9 protein in insulinoma cells to form a targetable mechanism of controlling insulinoma cell proliferation. Journal of Biological Chemistry 2014289 5386-5398. (https://doi.org/10.1074/jbc.M113.533612)

106 Chen JY, Cook MR, Pinchot SN, Kunnimalaiyaan M \& Chen H. MG-132 inhibits carcinoid growth and alters the neuroendocrine phenotype. Journal of Surgical Research 2010158 15-19. (https://doi. org/10.1016/j.jss.2009.05.032)

107 Kunnimalaiyaan M, Ndiaye M \& Chen H. Neuroendocrine tumour cell growth inhibition by ZM336372 through alterations in multiple signaling pathways. Surgery 2007142 959-964; discussion 959-964. (https://doi.org/10.1016/j.surg.2007.09.020)

108 Petrini I. Biology of MET: a double life between normal tissue repair and tumour progression. Annals of Translational Medicine 2015382.

109 Garajova I, Giovannetti E, Biasco G \& Peters GJ. c-Met as a target for personalized therapy. Translational Oncogenomics 20157 13-31. (https://doi.org/10.4137/TOG.S30534)

110 Sennino B, Ishiguro-Oonuma T, Wei Y, Naylor RM, Williamson CW, Bhagwandin V, Tabruyn SP, You WK, Chapman HA, Christensen JG, et al. Suppression of tumour invasion and metastasis by concurrent inhibition of c-Met and VEGF signaling in pancreatic http://www.endocrineconnections.org https://doi.org/10.1530/EC-17-0286
() 2018 The authors Published by Bioscientifica Ltd
This work is licensed under a Creative Commons Attribution-NonCommercial-NoDerivatives 4.0 International License. 
neuroendocrine tumours. Cancer Discovery 20122 270-287. (https:// doi.org/10.1158/2159-8290.CD-11-0240)

111 Sennino B, Ishiguro-Oonuma T, Schriver BJ, Christensen JG \& McDonald DM. Inhibition of c-Met reduces lymphatic metastasis in RIP-Tag2 transgenic mice. Cancer Research 201373 3692-3703. (https://doi.org/10.1158/0008-5472.CAN-12-2160)

112 Lynn KD \& Brekken RA. Anti-VEGF therapy revived by c-Met inhibition, but is c-Met the answer? Cancer Discovery 20122 211-213. (https://doi.org/10.1158/2159-8290.CD-12-0037)

113 Brandes F, Schmidt K, Wagner C, Redekopf J, Schlitt HJ, Geissler EK \& Lang SA. Targeting cMET with INC280 impairs tumour growth and improves efficacy of gemcitabine in a pancreatic cancer model. BMC Cancer 201515 71. (https://doi.org/10.1186/s12885-015-1064-9)

114 Moran-Jones K, Brown LM \& Samimi G. INC280, an orally available small molecule inhibitor of c-MET, reduces migration and adhesion in ovarian cancer cell models. Scientific Reports 2015511749. (https://doi.org/10.1038/srep11749)

115 Reuther C, Heinzle V, Spampatti M, Vlotides G, de Toni E, Spottl G, Maurer J, Nolting S, Goke B \& Auernhammer CJ. Cabozantinib and tivantinib, but not INC280, induce antiproliferative and antimigratory effects in human neuroendocrine tumour cells in vitro: evidence for 'off-target' effects not mediated by c-Met inhibition. Neuroendocrinology 2016103 383-401. (https://doi. org/10.1159/000439431)

116 Martin-Liberal J \& Larkin J. New RAF kinase inhibitors in cancer therapy. Expert Opinion on Pharmacotherapy 201415 1235-1245. (https://doi.org/10.1517/14656566.2014.911286)

117 Johnson DB \& Sosman JA. Therapeutic advances and treatment options in metastatic melanoma. JAMA Oncology $20151380-386$ (https://doi.org/10.1001/jamaoncol.2015.0565)

118 Gilbert JA, Adhikari LJ, Lloyd RV, Halfdanarson TR, Muders MH \& Ames MM. Molecular markers for novel therapeutic strategies in pancreatic endocrine tumours. Pancreas 201342 411-421. (https:// doi.org/10.1097/MPA.0b013e31826cb243)

119 Astsaturov IA, Cohen SJ, Engstrom PF, Gatalica Z, Bender RP, Basu GD $\&$ Millis SZ. Profiling of a global cohort of 1250 neuroendocrine tumours to identify multiple potential drug targets. Journal of Clinical Oncology 201432 214-214. (https://doi.org/10.1200/jco.2014.32.3_ suppl.214)

120 Oberg K. The genetics of neuroendocrine tumours. Seminars in Oncology 201340 37-44. (https://doi.org/10.1053/j. seminoncol.2012.11.005)

121 Ratner N \& Miller SJ. A RASopathy gene commonly mutated in cancer: the neurofibromatosis type 1 tumour suppressor. Nature Reviews Cancer 201515 290-301. (https://doi.org/10.1038/nrc3911)

122 Zitzmann K, de Toni E, von Ruden J, Brand S, Goke B, Laubender RP \& Auernhammer CJ. The novel Raf inhibitor Raf265 decreases Bcl-2 levels and confers TRAIL-sensitivity to neuroendocrine tumour cells Endocrine-Related Cancer 201118 277-285. (https://doi.org/10.1530/ ERC-10-0108)

123 Van Gompel JJ, Kunnimalaiyaan M, Holen K \& Chen H. ZM336372, a Raf-1 activator, suppresses growth and neuroendocrine hormone levels in carcinoid tumour cells. Molecular Cancer Therapeutics 20054 910-917. (https://doi.org/10.1158/1535-7163.MCT-04-0334)

124 Cook MR, Pinchot SN, Jaskula-Sztul R, Luo J, Kunnimalaiyaan M \& Chen H. Identification of a novel Raf-1 pathway activator that inhibits gastrointestinal carcinoid cell growth. Molecular Cancer Therapeutics 20109 429-437. (https://doi.org/10.1158/1535-7163. MCT-09-0718)

125 Somnay Y, Chen H \& Kunnimalaiyaan M. Synergistic effect of pasireotide and teriflunomide in carcinoids in vitro. Neuroendocrinology 201397 183-192. (https://doi. org/10.1159/000341810)

126 Fazio N, Abdel-Rahman O, Spada F, Galdy S, De Dosso S, Capdevila J $\&$ Scarpa A. RAF signaling in neuroendocrine neoplasms: from bench to bedside. Cancer Treatment Reviews 201440 974-979. (https://doi. org/10.1016/j.ctrv.2014.06.009)

127 Sippel RS, Carpenter JE, Kunnimalaiyaan M, Lagerholm S \& Chen H. Raf-1 activation suppresses neuroendocrine marker and hormone levels in human gastrointestinal carcinoid cells. American Journal of Physiology: Gastrointestinal and Liver Physiology 2003285 G245-G254. (https://doi.org/10.1152/ajpgi.00420.2002)

128 Ning L, Chen H \& Kunnimalaiyaan M. Focal adhesion kinase, a downstream mediator of Raf-1 signaling, suppresses cellular adhesion, migration, and neuroendocrine markers in BON carcinoid cells. Molecular Cancer Research 20108 775-782. (https://doi. org/10.1158/1541-7786.MCR-09-0525)

129 Greenblatt DY, Kunnimalaiyaan M \& Chen H. Raf-1 activation in gastrointestinal carcinoid cells decreases tumour cell adhesion. American Journal of Surgery 2007193 331-335; discussion 335 (https://doi.org/10.1016/j.amjsurg.2006.09.016)

130 Hatzivassiliou G, Song K, Yen I, Brandhuber BJ, Anderson DJ, Alvarado R, Ludlam MJ, Stokoe D, Gloor SL, Vigers G, et al. RAF inhibitors prime wild-type RAF to activate the MAPK pathway and enhance growth. Nature 2010464 431-435. (https://doi.org/10.1038/ nature08833)

131 Hall-Jackson CA, Eyers PA, Cohen P, Goedert M, Boyle FT, Hewitt N, Plant H \& Hedge P. Paradoxical activation of Raf by a novel Raf inhibitor. Chemistry and Biology 19996 559-568.

132 Grant S. Cotargeting survival signaling pathways in cancer. Journal of Clinical Investigation $2008 \mathbf{1 1 8} 3003-3006$.

133 Carracedo A, Ma L, Teruya-Feldstein J, Rojo F, Salmena L, Alimonti A, Egia A, Sasaki AT, Thomas G, Kozma SC, et al. Inhibition of mTORC1 leads to MAPK pathway activation through a PI3K-dependent feedback loop in human cancer. Journal of Clinical Investigation 2008 118 3065-3074.

134 Kinkade CW, Castillo-Martin M, Puzio-Kuter A, Yan J, Foster TH, Gao H, Sun Y, Ouyang X, Gerald WL, Cordon-Cardo C, et al. Targeting AKT/mTOR and ERK MAPK signaling inhibits hormonerefractory prostate cancer in a preclinical mouse model. Journal of Clinical Investigation 2008118 3051-3064.

135 Cochrane CR, Szczepny A, Watkins DN \& Cain JE. hedgehog signaling in the maintenance of cancer stem cells. Cancers 20157 1554-1585. (https://doi.org/10.3390/cancers7030851)

136 Takebe N, Miele L, Harris PJ, Jeong W, Bando H, Kahn M, Yang SX\& Ivy SP. Targeting Notch, Hedgehog, and Wnt pathways in cancer stem cells: clinical update. Nature Reviews Clinical Oncology 201512 445-464. (https://doi.org/10.1038/nrclinonc.2015.61)

137 Gonnissen A, Isebaert S \& Haustermans K. Targeting the Hedgehog signaling pathway in cancer: beyond Smoothened. Oncotarget 20156 13899-13913. (https://doi.org/10.18632/oncotarget.4224)

138 Justilien V \& Fields AP. Molecular pathways: novel approaches for improved therapeutic targeting of Hedgehog signaling in cancer stem cells. Clinical Cancer Research 201521 505-513. (https://doi. org/10.1158/1078-0432.CCR-14-0507)

139 Nix NM, Burdine O \& Walker M. Vismodegib: first-in-class hedgehog pathway inhibitor for metastatic or locally advanced basal cell carcinoma. Journal of the Advanced Practitioner in Oncology 20145 294-296.

140 Booms P, Harth M, Sader R \& Ghanaati S. Vismodegib hedgehogsignaling inhibition and treatment of basal cell carcinomas as well as keratocystic odontogenic tumours in Gorlin syndrome. Annals of Maxillofacial Surgery 20155 14-19. (https://doi.org/10.4103/2231 0746.161049)

141 Grande E, Capdevila J, Barriuso J, Anton-Aparicio L \& Castellano D. Gastroenteropancreatic neuroendocrine tumour cancer stem cells: do they exist? Cancer Metastasis Reviews 201231 47-53. (https://doi org/10.1007/s10555-011-9328-6)

142 Fendrich V, Waldmann J, Esni F, Ramaswamy A, Mullendore M, Buchholz M, Maitra A \& Feldmann G. Snail and Sonic Hedgehog http://www.endocrineconnections.org

https://doi.org/10.1530/EC-17-0286
(C) 2018 The authors Published by Bioscientifica Ltd
This work is licensed under a Creative Common Attribution-NonCommercial-NoDerivatives 4.0 International License. 
activation in neuroendocrine tumours of the ileum. Endocrine-Related Cancer 200714 865-874. (https://doi.org/10.1677/ERC-07-0108)

143 Gurung B, Hua X, Runske M, Bennett B, LiVolsi V, Roses R, Fraker DA $\&$ Metz DC. PTCH 1 staining of pancreatic neuroendocrine tumour (PNET) samples from patients with and without multiple endocrine neoplasia (MEN-1) syndrome reveals a potential therapeutic target. Cancer Biology and Therapy 201516 219-224.

144 Fendrich V, Ramerth R, Waldmann J, Maschuw K, Langer P, Bartsch DK, Slater EP, Ramaswamy A \& Rothmund M. Sonic hedgehog and pancreatic-duodenal homeobox 1 expression distinguish between duodenal and pancreatic gastrinomas. EndocrineRelated Cancer 200916 613-622. (https://doi.org/10.1677/ERC-080204)

145 Shida T, Furuya M, Nikaido T, Hasegawa M, Koda K, Oda K, Miyazaki M, Kishimoto T, Nakatani Y \& Ishikura H. Sonic HedgehogGli1 signaling pathway might become an effective therapeutic target in gastrointestinal neuroendocrine carcinomas. Cancer Biology and Therapy 20065 1530-1538.

146 Park KS, Martelotto LG, Peifer M, Sos ML, Karnezis AN, Mahjoub MR, Bernard K, Conklin JF, Szczepny A, Yuan J, et al. A crucial requirement for Hedgehog signaling in small cell lung cancer. Nature Medicine 201117 1504-1508. (https://doi.org/10.1038/nm.2473)

147 Gurung B, Feng Z, Iwamoto DV, Thiel A, Jin G, Fan CM, Ng JM, Curran T \& Hua X. Menin epigenetically represses Hedgehog signaling in MEN1 tumour syndrome. Cancer Research 201373 2650-2658. (https://doi.org/10.1158/0008-5472.CAN-12-3158)

148 Martinelli DC \& Fan CM. Gas1 extends the range of Hedgehog action by facilitating its signaling. Genes and Development $2007 \mathbf{2 1}$ 1231-1243.

149 Gurung B, Feng Z \& Hua X. Menin directly represses Gli1 expression independent of canonical Hedgehog signaling. Molecular Cancer Research 201311 1215-1222. (https://doi.org/10.1158/1541-7786. MCR-13-0170)

150 Gurung B \& Hua X. Menin/PRMT5/hedgehog signaling: a potential target for the treatment of multiple endocrine neoplasia type 1 tumours. Epigenomics 20135 469-471. (https://doi.org/10.2217/ epi.13.47)

151 Chen JK, Taipale J, Cooper MK \& Beachy PA. Inhibition of Hedgehog signaling by direct binding of cyclopamine to Smoothened. Genes and Development 200216 2743-2748.

152 Taipale J, Chen JK, Cooper MK, Wang B, Mann RK, Milenkovic L, Scott MP \& Beachy PA. Effects of oncogenic mutations in Smoothened and Patched can be reversed by cyclopamine. Nature 2000406 1005-1009. (https://doi.org/10.1038/35023008)

153 Fendrich V, Rehm J, Waldmann J, Buchholz M, Christofori G, Lauth M, Slater EP \& Bartsch DK. Hedgehog inhibition with cyclopamine represses tumour growth and prolongs survival in a transgenic mouse model of islet cell tumours. Annals of Surgery 2011 253 546-552. (https://doi.org/10.1097/SLA.0b013e31820a5bbe)

154 Fendrich V, Wiese D, Waldmann J, Lauth M, Heverhagen AE, Rehm J \& Bartsch DK. Hedgehog inhibition with the orally bioavailable Smo antagonist LDE225 represses tumour growth and prolongs survival in a transgenic mouse model of islet cell neoplasms. Annals of Surgery 2011254 818-823; discussion 823. (https://doi.org/10.1097/ SLA.0b013e318236bc0f)

155 Spetz J, Langen B, Rudqvist N, Parris TZ, Helou K, Nilsson O \& Forssell-Aronsson E. Hedgehog inhibitor sonidegib potentiates 177Lu-octreotate therapy of GOT1 human small intestine neuroendocrine tumours in nude mice. BMC Cancer 201717528. (https://doi.org/10.1186/s12885-017-3524-x)

156 Crabtree JS, Singleton CS \& Miele L. Notch signaling in neuroendocrine tumours. Frontiers in Oncology 2016694.

157 Capaccione KM \& Pine SR. The Notch signaling pathway as a mediator of tumour survival. Carcinogenesis 201334 1420-1430. (https://doi.org/10.1093/carcin/bgt127)
158 Bertrand FE, Angus CW, Partis WJ \& Sigounas G. Developmental pathways in colon cancer: crosstalk between WNT, BMP, Hedgehog and Notch. Cell Cycle 201211 4344-4351. (https://doi.org/10.4161/ cc.22134)

159 Guo S, Liu M \& Gonzalez-Perez RR. Role of Notch and its oncogenic signaling crosstalk in breast cancer. Biochimica et Biophysica Acta 2011 1815 197-213.

160 Radtke F \& Raj K. The role of Notch in tumourigenesis: oncogene or tumour suppressor? Nature Reviews Cancer 20033 756-767. (https:// doi.org/10.1038/nrc1186)

161 Lobry C, Oh P, Mansour MR, Look AT \& Aifantis I. Notch signaling: switching an oncogene to a tumour suppressor. Blood 2014123 2451-2459. (https://doi.org/10.1182/blood-2013-08-355818)

162 South AP, Cho RJ \& Aster JC. The double-edged sword of Notch signaling in cancer. Seminars in Cell and Developmental Biology 2012 23 458-464.

163 Espinoza I \& Miele L. Notch inhibitors for cancer treatment. Pharmacology and Therapeutics 2013139 95-110.

164 Golde TE, Koo EH, Felsenstein KM, Osborne BA \& Miele L. gamma-Secretase inhibitors and modulators. Biochimica et Biophysica Acta 20131828 2898-2907. (https://doi.org/10.1016/j. bbamem.2013.06.005)

165 Zarebczan B \& Chen H. Signaling mechanisms in neuroendocrine tumours as targets for therapy. Endocrinology and Metabolism Clinics of North America 201039 801-810. (https://doi.org/10.1016/j. ecl.2010.08.002)

166 Kunnimalaiyaan M, Traeger K \& Chen H. Conservation of the Notch1 signaling pathway in gastrointestinal carcinoid cells. American Journal of Physiology: Gastrointestinal and Liver Physiology 2005289 G636-G642.

167 Pinchot SN, Jaskula-Sztul R, Ning L, Peters NR, Cook MR, Kunnimalaiyaan $\mathrm{M} \&$ Chen $\mathrm{H}$. Identification and validation of Notch pathway activating compounds through a novel high-throughput screening method. Cancer 2011117 1386-1398. (https://doi. org/10.1002/cncr.25652)

168 Kunnimalaiyaan M, Yan S, Wong F, Zhang YW \& Chen H. Hairy Enhancer of Split-1 (HES-1), a Notch1 effector, inhibits the growth of carcinoid tumour cells. Surgery 2005138 1137-1142; discussion 1142. (https://doi.org/10.1016/j.surg.2005.05.027)

169 Nakakura EK, Sriuranpong VR, Kunnimalaiyaan M, Hsiao EC, Schuebel KE, Borges MW, Jin N, Collins BJ, Nelkin BD, Chen H, et al. Regulation of neuroendocrine differentiation in gastrointestinal carcinoid tumour cells by notch signaling. Journal of Clinical Endocrinology and Metabolism 200590 4350-4356. (https://doi. org/10.1210/jc.2005-0540)

170 Sriuranpong V, Borges MW, Strock CL, Nakakura EK, Watkins DN, Blaumueller CM, Nelkin BD \& Ball DW. Notch signaling induces rapid degradation of achaete-scute homolog 1. Molecular and Cellular Biology 200222 3129-3139. (https://doi.org/10.1128/MCB.22.9.31293139.2002)

171 Johansson TA, Westin G \& Skogseid B. Identification of Achaete-scute complex-like 1 (ASCL1) target genes and evaluation of DKK1 and TPH1 expression in pancreatic endocrine tumours. BMC Cancer 2009 9 321. (https://doi.org/10.1186/1471-2407-9-321)

172 Greenblatt DY, Vaccaro AM, Jaskula-Sztul R, Ning L, Haymart M, Kunnimalaiyaan M \& Chen H. Valproic acid activates notch-1 signaling and regulates the neuroendocrine phenotype in carcinoid cancer cells. Oncologist 200712 942-951. (https://doi.org/10.1634/ theoncologist.12-8-942)

173 Platta CS, Greenblatt DY, Kunnimalaiyaan M \& Chen H. Valproic acid induces Notch1 signaling in small cell lung cancer cells. Journal of Surgical Research 2008148 31-37. (https://doi.org/10.1016/j. jss.2008.03.008)

174 Mohammed TA, Holen KD, Jaskula-Sztul R, Mulkerin D, Lubner SJ, Schelman WR, Eickhoff J, Chen H \& Loconte NK. A pilot phase II http://www.endocrineconnections.org https://doi.org/10.1530/EC-17-0286
C 2018 The authors Published by Bioscientifica Ltd
This work is licensed under a Creative Commons Attribution-NonCommercial-NoDerivatives 4.0 International License. 
study of valproic acid for treatment of low-grade neuroendocrine carcinoma. Oncologist 201116 835-843. (https://doi.org/10.1634/ theoncologist.2011-0031)

175 Singh CK, Ndiaye MA \& Ahmad N. Resveratrol and cancer: challenges for clinical translation. Biochimica et Biophysica Acta 2015 1852 1178-1185. (https://doi.org/10.1016/j.bbadis.2014.11.004)

176 Wyche TP, Dammalapati A, Cho H, Harrison AD, Kwon GS, Chen H, Bugni TS \& Jaskula-Sztul R. Thiocoraline activates the Notch pathway in carcinoids and reduces tumour progression in vivo. Cancer Gene Therapy 201421 518-525. (https://doi.org/10.1038/cgt.2014.57)

177 Polakis P. Wnt signaling in cancer. Cold Spring Harbor Perspectives in Biology 20124 a008052.

178 Kim JT, Li J, Jang ER, Gulhati P, Rychahou PG, Napier DL, Wang C, Weiss HL, Lee EY, Anthony L, et al. Deregulation of Wnt/betacatenin signaling through genetic or epigenetic alterations in human neuroendocrine tumours. Carcinogenesis 201334 953-961. (https:// doi.org/10.1093/carcin/bgt018)

179 Bottarelli L, Azzoni C, Pizzi S, D'Adda T, Silini EM, Bordi C \& Rindi G. Adenomatous polyposis coli gene involvement in ileal enterochromaffin cell neuroendocrine neoplasms. Human Pathology 201344 2736-2742. (https://doi.org/10.1016/j. humpath.2013.06.019)

180 Estrella JS, Taggart MW, Rashid A \& Abraham SC. Low-grade neuroendocrine tumours arising in intestinal adenomas: evidence for alterations in the adenomatous polyposis coli/beta-catenin pathway. Human Pathology 201445 2051-2058. (https://doi.org/10.1016/j. humpath.2014.07.001)

181 Chen G, A J, Wang M, Farley S, Lee LY, Lee LC \& Sawicki MP. Menin promotes the Wnt signaling pathway in pancreatic endocrine cells. Molecular Cancer Research 20086 1894-1907.

182 Jiang X, Cao Y, Li F, Su Y, Li Y, Peng Y, Cheng Y, Zhang C, Wang W \& Ning G. Targeting beta-catenin signaling for therapeutic intervention in MEN1-deficient pancreatic neuroendocrine tumours. Nature Communications 20145 5809. (https://doi.org/10.1038/ncomms6809)

183 Kim JT, Liu C, Zaytseva YY, Weiss HL, Townsend CM Jr \& Evers BM. Neurotensin, a novel target of Wnt/beta-catenin pathway, promotes growth of neuroendocrine tumour cells. International Journal of Cancer 2015136 1475-1481. (https://doi.org/10.1002/ijc.29123)

184 Saupe F, Schwenzer A, Jia Y, Gasser I, Spenle C, Langlois B, Kammerer M, Lefebvre O, Hlushchuk R, Rupp T, et al. Tenascin-C downregulates wnt inhibitor dickkopf-1, promoting tumourigenesis in a neuroendocrine tumour model. Cell Reports 20135 482-492. (https://doi.org/10.1016/j.celrep.2013.09.014)

185 Le PN, McDermott JD \& Jimeno A. Targeting the Wnt pathway in human cancers: therapeutic targeting with a focus on OMP-54F28. Pharmacology and Therapeutics 2015146 1-11.

186 Sebio A, Kahn M \& Lenz HJ. The potential of targeting Wnt/betacatenin in colon cancer. Expert Opinion on Therapeutic Targets 201418 611-615. (https://doi.org/10.1517/14728222.2014.906580)

187 Polakis P. Drugging Wnt signalling in cancer. EMBO Journal 201231 2737-2746. (https://doi.org/10.1038/emboj.2012.126)

188 Akhurst RJ \& Hata A. Targeting the TGFbeta signalling pathway in disease. Nature Reviews Drug Discovery 201211 790-811. (https://doi. org/10.1038/nrd3810)

189 Gilbert JA, Adhikari LJ, Lloyd RV, Rubin J, Haluska P, Carboni JM, Gottardis MM \& Ames MM. Molecular markers for novel therapies in neuroendocrine (carcinoid) tumours. Endocrine-Related Cancer 2010 17 623-636. (https://doi.org/10.1677/ERC-09-0318)

190 Kidd M, Schimmack S, Lawrence B, Alaimo D \& Modlin IM. EGFR/ TGFalpha and TGFbeta/CTGF signaling in neuroendocrine neoplasia: theoretical therapeutic targets. Neuroendocrinology 201397 35-44. (https://doi.org/10.1159/000334891)

191 Inoue K, Fry EA \& Frazier DP. Transcription factors that interact with p53 and Mdm2. International Journal of Cancer 2016138 1577-1585. (https://doi.org/10.1002/ijc.29663)
192 Meek DW. Regulation of the p53 response and its relationship to cancer. Biochemical Journal 2015469 325-346. (https://doi. org/10.1042/BJ20150517)

193 Muller PA \& Vousden KH. Mutant p53 in cancer: new functions and therapeutic opportunities. Cancer Cell 201425 304-317. (https://doi. org/10.1016/j.ccr.2014.01.021)

194 Wade M, Li YC \& Wahl GM. MDM2, MDMX and p53 in oncogenesis and cancer therapy. Nature Reviews Cancer 201313 83-96. (https:// doi.org/10.1038/nrc3430)

195 Zhao Y, Aguilar A, Bernard D \& Wang S. Small-molecule inhibitors of the MDM2-p53 protein-protein interaction (MDM2 Inhibitors) in clinical trials for cancer treatment. Journal of Medicinal Chemistry 201558 1038-1052. (https://doi.org/10.1021/jm501092z)

196 Lu X, Ma O, Nguyen TA, Jones SN, Oren M \& Donehower LA. The Wip1 Phosphatase acts as a gatekeeper in the p53-Mdm2 autoregulatory loop. Cancer Cell 200712 342-354. (https://doi. org/10.1016/j.ccr.2007.08.033)

197 Stracker TH, Roig I, Knobel PA \& Marjanovic M. The ATM signaling network in development and disease. Frontiers in Genetics 2013437

198 Brazina J, Svadlenka J, Macurek L, Andera L, Hodny Z, Bartek J \& Hanzlikova H. DNA damage-induced regulatory interplay between DAXX, p53, ATM kinase and Wip1 phosphatase. Cell Cycle 201514 375-387. (https://doi.org/10.4161/15384101.2014.988019)

199 Shin JU, Lee CH, Lee KT, Lee JK, Lee KH, Kim KM, Kim KM, Park SM \& Rhee JC. Prognostic significance of ATM and cyclin B1 in pancreatic neuroendocrine tumour. Tumour Biology 201233 1645-1651. (https://doi.org/10.1007/s13277-012-0420-5)

200 Lee J, Sung CO, Lee EJ, Do IG, Kim HC, Yoon SH, Lee WY, Chun HK, Kim KM \& Park YS. Metastasis of neuroendocrine tumours are characterized by increased cell proliferation and reduced expression of the ATM gene. PLoS ONE 20127 e34456. (https://doi.org/10.1371/ journal.pone.0034456)

201 Casanovas O, Hager JH, Chun MG \& Hanahan D. Incomplete inhibition of the $\mathrm{Rb}$ tumour suppressor pathway in the context of inactivated p53 is sufficient for pancreatic islet tumourigenesis. Oncogene 200524 6597-6604. (https://doi.org/10.1038/ sj.onc.1208823)

202 Glenn ST, Jones CA, Sexton S, LeVea CM, Caraker SM, Hajduczok G $\&$ Gross KW. Conditional deletion of p53 and Rb in the reninexpressing compartment of the pancreas leads to a highly penetran metastatic pancreatic neuroendocrine carcinoma. Oncogene 201433 5706-5715. (https://doi.org/10.1038/onc.2013.514)

203 Kawase T, Ohki R, Shibata T, Tsutsumi S, Kamimura N, Inazawa J, Ohta T, Ichikawa H, Aburatani H, Tashiro F, et al. PH domain-only protein PHLDA3 is a p53-regulated repressor of Akt. Cell 2009136 535-550. (https://doi.org/10.1016/j.cell.2008.12.002)

204 Ohki R, Saito K, Chen Y, Kawase T, Hiraoka N, Saigawa R, Minegishi M, Aita Y, Yanai G, Shimizu H, et al. PHLDA3 is a novel tumour suppressor of pancreatic neuroendocrine tumours. PNAS 2014111 E2404-E2413. (https://doi.org/10.1073/pnas.1319962111)

205 Grabowski P, Schrader J, Wagner J, Horsch D, Arnold R, Arnold CN, Georgieva I, Stein H, Zeitz M, Daniel PT, et al. Loss of nuclear p27 expression and its prognostic role in relation to cyclin E and p53 mutation in gastroenteropancreatic neuroendocrine tumours. Clinical Cancer Research 200814 7378-7384. (https://doi.org/10.1158/10780432.CCR-08-0698)

$206 \mathrm{Hu}$ W, Feng Z, Modica I, Klimstra DS, Song L, Allen PJ, Brennan MF, Levine AJ \& Tang LH. Gene amplifications in well-differentiated pancreatic neuroendocrine tumours inactivate the p53 pathway. Genes and Cancer $20101360-368$.

207 Zhang B, Golding BT \& Hardcastle IR. Small-molecule MDM2-p53 inhibitors: recent advances. Future Medicinal Chemistry 20157 631-645. (https://doi.org/10.4155/fmc.15.13)

208 Reuther C, Heinzle V, Nolting S, Herterich S, Hahner S, Halilovic E, Jeay S, Wuerthner JU, Aristizabal Prada ET, Spottl G, et al. The HDM2 http://www.endocrineconnections.org

https://doi.org/10.1530/EC-17-0286 (c) 2018 The authors Published by Bioscientifica Ltd
This work is licensed under a Creative Commons Attribution-NonCommercial-NoDerivatives 4.0 International License. 
(MDM2) inhibitor NVP-CGM097 inhibits tumour cell proliferation and shows additive effects with 5-fluorouracil on the p53 - p21 - Rb - E2F1 cascade in the p53wildtype neuroendocrine tumour cell line GOT1. Neuroendocrinology 2016106 1-19.

209 Briest F \& Grabowski P. The p53 network as therapeutic target in gastroenteropancreatic neuroendocrine neoplasms. Cancer Treatment Reviews 201541 423-430. (https://doi.org/10.1016/j. ctrv.2015.03.006)

210 Lv PC, Sun J \& Zhu HL. Recent advances of p53-MDM2 small molecule inhibitors (2011-present). Current Medicinal Chemistry 201522 618-626. (https://doi.org/10.2174/0929867322666141128 162557)

211 Boltjes A, Huang Y, van de Velde R, Rijkee L, Wolf S, Gaugler J, Lesniak K, Guzik K, Holak TA \& Domling A. Fragment-based library generation for the discovery of a peptidomimetic p53-Mdm4 inhibitor. ACS Combinatorial Science 201416 393-396. (https://doi. org/10.1021/co500026b)

212 Gilmartin AG, Faitg TH, Richter M, Groy A, Seefeld MA, Darcy MG, Peng X, Federowicz K, Yang J, Zhang SY, et al. Allosteric Wip1 phosphatase inhibition through flap-subdomain interaction. Nature Chemical Biology 201410 181-187. (https://doi.org/10.1038/ nchembio.1427)

213 Marinoni I, Kurrer AS, Vassella E, Dettmer M, Rudolph T, Banz V, Hunger F, Pasquinelli S, Speel EJ \& Perren A. Loss of DAXX and ATRX are associated with chromosome instability and reduced survival of patients with pancreatic neuroendocrine tumours. Gastroenterology 2014146 453.e455-460.e455. (https://doi.org/10.1053/j. gastro.2013.10.020)

214 Law ME, Corsino PE, Narayan S \& Law BK. Cyclin-dependent kinase inhibitors as anticancer therapeutics. Molecular Pharmacology 201588 846-852. (https://doi.org/10.1124/mol.115.099325)

215 Peyressatre M, Prevel C, Pellerano M \& Morris MC. Targeting cyclindependent kinases in human cancers: from small molecules to peptide inhibitors. Cancers 20157 179-237. (https://doi.org/10.3390/ cancers7010179)

216 Malumbres M \& Perez de Castro I. Aurora kinase A inhibitors: promising agents in antitumoural therapy. Expert Opinion on Therapeutic Targets 201418 1377-1393.

217 Cicenas J \& Valius M. The CDK inhibitors in cancer research and therapy. Journal of Cancer Research and Clinical Oncology 2011137 1409-1418. (https://doi.org/10.1007/s00432-011-1039-4)

218 Cicenas J, Kalyan K, Sorokinas A, Jatulyte A, Valiunas D, Kaupinis A \& Valius M. Highlights of the latest advances in research on CDK inhibitors. Cancers 20146 2224-2242. (https://doi.org/10.3390/ cancers6042224)

219 Dickson MA. Molecular pathways: CDK4 inhibitors for cancer therapy. Clinical Cancer Research 201420 3379-3383. (https://doi. org/10.1158/1078-0432.CCR-13-1551)

220 Malinkova V, Vylicil J \& Krystof V. Cyclin-dependent kinase inhibitors for cancer therapy: a patent review (2009-2014). Expert Opinion on Therapeutic Patents 201525 953-970. (https://doi.org/10.1 517/13543776.2015.1045414)

221 Turner NC, Ro J, Andre F, Loi S, Verma S, Iwata H, Harbeck N, Loibl S, Huang Bartlett C, Zhang K, et al. Palbociclib in hormone-receptorpositive advanced breast cancer. New England Journal of Medicine 2015 373 209-219. (https://doi.org/10.1056/NEJMoa1505270)

222 Cristofanilli M, Turner NC, Bondarenko I, Ro J, Im SA, Masuda N, Colleoni M, DeMichele A, Loi S, Verma S, et al. Fulvestrant plus palbociclib versus fulvestrant plus placebo for treatment of hormonereceptor-positive, HER2-negative metastatic breast cancer that progressed on previous endocrine therapy (PALOMA-3): final analysis of the multicentre, double-blind, phase 3 randomised controlled trial. Lancet Oncology 201617 425-439. (https://doi.org/10.1016/ S1470-2045(15)00613-0)
223 VanArsdale T, Boshoff C, Arndt KT \& Abraham RT. Molecular pathways: targeting the cyclin D-CDK4/6 axis for cancer treatment. Clinical Cancer Research 201521 2905-2910. (https://doi. org/10.1158/1078-0432.CCR-14-0816)

224 Gillam MP, Nimbalkar D, Sun L, Christov K, Ray D, Kaldis P, Liu X \& Kiyokawa H. MEN1 tumourigenesis in the pituitary and pancreatic islet requires Cdk4 but not Cdk2. Oncogene 201534 932-938. (https://doi.org/10.1038/onc.2014.3)

225 Tang LH, Contractor T, Clausen R, Klimstra DS, Du YC, Allen PJ, Brennan MF, Levine AJ \& Harris CR. Attenuation of the retinoblastoma pathway in pancreatic neuroendocrine tumours because of increased cdk4/cdk6. Clinical Cancer Research 201218 4612-4620. (https://doi.org/10.1158/1078-0432.CCR-11-3264)

226 Scholz A, Wagner K, Welzel M, Remlinger F, Wiedenmann B, Siemeister G, Rosewicz S \& Detjen KM. The oral multitarget tumour growth inhibitor, ZK 304709, inhibits growth of pancreatic neuroendocrine tumours in an orthotopic mouse model. Gut 2009 58 261-270. (https://doi.org/10.1136/gut.2007.146415)

227 Aristizabal Prada ET, Nolting S, Spoettl G, Maurer J \& Auernhammer CJ. The novel cyclin-dependent kinase 4/6 inhibitor ribociclib (LEE011) alone and in dual-targeting approaches demonstrates antitumoural efficacy in neuroendocrine tumours in vitro. Neuroendocrinology 2017 106 58-73. (https://doi.org/10.1159/000463386)

228 Chu IM, Hengst L \& Slingerland JM. The Cdk inhibitor p27 in human cancer: prognostic potential and relevance to anticancer therapy. Nature Reviews Cancer 20088 253-267. (https://doi. org/10.1038/nrc2347)

229 Pellegata NS, Quintanilla-Martinez L, Siggelkow H, Samson E, Bink K, Hofler H, Fend F, Graw J \& Atkinson MJ. Germ-line mutations in p27Kip1 cause a multiple endocrine neoplasia syndrome in rats and humans. PNAS 2006103 15558-15563. (https://doi.org/10.1073/ pnas.0603877103)

230 Lee M \& Pellegata NS. Multiple endocrine neoplasia type 4. Frontiers of Hormone Research $2013 \mathbf{4 1} 63-78$.

231 Karpathakis A, Dibra H, Pipinikas C, Feber A, Morris T, Francis J, Oukrif D, Mandair D, Pericleous M, Mohmaduvesh M, et al. Prognostic impact of novel molecular subtypes of small intestinal neuroendocrine tumour. Clinical Cancer Research 201622 250-258. (https://doi.org/10.1158/1078-0432.CCR-15-0373)

232 Crona J, Gustavsson T, Norlen O, Edfeldt K, Akerstrom T, Westin G, Hellman P, Bjorklund P \& Stalberg P. Somatic mutations and genetic heterogeneity at the CDKN1B locus in small intestinal neuroendocrine tumours. Annals of Surgical Oncology 201522 (Supplement 3) S1428-S1435. (https://doi.org/10.1245/s10434-0144351-9)

233 Circelli L, Ramundo V, Marotta V, Sciammarella C, Marciello F, Del Prete M, Sabatino L, Pasquali D, Izzo F, Scala S, et al. Prognostic role of the CDNK1B V109G polymorphism in multiple endocrine neoplasia type 1. Journal of Cellular and Molecular Medicine 201519 1735-1741. (https://doi.org/10.1111/jcmm.12552)

234 Kim HS, Lee HS, Nam KH, Choi J \& Kim WH. p27 loss is associated with poor prognosis in gastroenteropancreatic neuroendocrine tumours. Cancer Research and Treatment 201446 383-392. (https:// doi.org/10.4143/crt.2013.102)

235 Ooi LC, Watanabe N, Futamura Y, Sulaiman SF, Darah I \& Osada H. Identification of small molecule inhibitors of p27(Kip1) ubiquitination by high-throughput screening. Cancer Science 2013 104 1461-1467. (https://doi.org/10.1111/cas.12246)

236 Bochis OV, Irimie A, Pichler M \& Berindan-Neagoe I. The role of Skp2 and its substrate CDKN1B (p27) in colorectal cancer. Journal of Gastrointestinal and Liver Diseases 201524 225-234.

237 Hao Z \& Huang S. E3 ubiquitin ligase Skp2 as an attractive target in cancer therapy. Frontiers in Bioscience 201520 474-490. (https://doi. org/10.2741/4320) http://www.endocrineconnections.org https://doi.org/10.1530/EC-17-0286
() 2018 The authors Published by Bioscientifica Ltd
This work is licensed under a Creative Commons Attribution-NonCommercial-NoDerivatives 4.0 International License. 
238 Butler LM, Ferraldeschi R, Armstrong HK, Centenera MM \& Workman P. Maximizing the therapeutic potential of HSP90 inhibitors. Molecular Cancer Research 201513 1445-1451. (https:// doi.org/10.1158/1541-7786.MCR-15-0234)

239 Lianos GD, Alexiou GA, Mangano A, Mangano A, Rausei S, Boni L, Dionigi G \& Roukos DH. The role of heat shock proteins in cancer Cancer Letters 2015360 114-118. (https://doi.org/10.1016/j. canlet.2015.02.026)

240 Sidera K \& Patsavoudi E. HSP90 inhibitors: current development and potential in cancer therapy. Recent Patents on Anti-Cancer Drug Discovery 20149 1-20. (https://doi.org/10.2174/1574892811308999 0031)

241 Zitzmann K, Ailer G, Vlotides G, Spoettl G, Maurer J, Goke B, Beuschlein F \& Auernhammer CJ. Potent antitumour activity of the novel HSP90 inhibitors AUY922 and HSP990 in neuroendocrine carcinoid cells. International Journal of Oncology 201343 1824-1832. (https://doi.org/10.3892/ijo.2013.2130)

242 Gloesenkamp C, Nitzsche B, Lim AR, Normant E, Vosburgh E, Schrader M, Ocker M, Scherubl H \& Hopfner M. Heat shock protein 90 is a promising target for effective growth inhibition of gastrointestinal neuroendocrine tumours. International Journal of Oncology 201240 1659-1667.

243 Katsha A, Belkhiri A, Goff L \& El-Rifai W. Aurora kinase A in gastrointestinal cancers: time to target. Molecular Cancer 201514106. (https://doi.org/10.1186/s12943-015-0375-4)

244 Katayama H, Sasai K, Kawai H, Yuan ZM, Bondaruk J, Suzuki F, Fujii S, Arlinghaus RB, Czerniak BA \& Sen S. Phosphorylation by aurora kinase A induces Mdm2-mediated destabilization and inhibition of p53. Nature Genetics 200436 55-62. (https://doi. org/10.1038/ng1279)

245 Fraedrich K, Schrader J, Ittrich H, Keller G, Gontarewicz A, Matzat V, Kromminga A, Pace A, Moll J, Blaker M, et al. Targeting aurora kinases with danusertib (PHA-739358) inhibits growth of liver metastases from gastroenteropancreatic neuroendocrine tumours in an orthotopic xenograft model. Clinical Cancer Research 201218 4621-4632. (https://doi.org/10.1158/1078-0432.CCR-11-2968)

246 Georgieva I, Koychev D, Wang Y, Holstein J, Hopfenmuller W, Zeitz M \& Grabowski P. ZM447439, a novel promising aurora kinase inhibitor, provokes antiproliferative and proapoptotic effects alone and in combination with bio- and chemotherapeutic agents in gastroenteropancreatic neuroendocrine tumour cell lines. Neuroendocrinology 201091 121-130. (https://doi. org/10.1159/000258705)

247 Park J, Thomas S \& Munster PN. Epigenetic modulation with histone deacetylase inhibitors in combination with immunotherapy. Epigenomics 20157 641-652. (https://doi.org/10.2217/epi.15.16)

248 Ma N, Luo Y, Wang Y, Liao C, Ye WC \& Jiang S. Selective histone deacetylase inhibitors with anticancer activity. Current Topics in Medicinal Chemistry 201616 415-426. (https://doi.org/10.2174/1568 026615666150813145629)

249 Ruiz R, Raez LE \& Rolfo C. Entinostat (SNDX-275) for the treatment of non-small cell lung cancer. Expert Opinion on Investigational Drugs 2015 24 1101-1109. (https://doi.org/10.1517/13543784.2015.1056779)

250 Chun P. Histone deacetylase inhibitors in hematological malignancies and solid tumours. Archives of Pharmacal Research 2015 38 933-949. (https://doi.org/10.1007/s12272-015-0571-1)

251 Karpathakis A, Dibra H \& Thirlwell C. Neuroendocrine tumours: cracking the epigenetic code. Endocrine-Related Cancer 201320 R65-R82. (https://doi.org/10.1530/ERC-12-0338)

252 Larsson C. Epigenetic aspects on therapy development for gastroenteropancreatic neuroendocrine tumours. Neuroendocrinology 201397 19-25. (https://doi.org/10.1159/000336087)

253 Feng Z, Ma J \& Hua X. Epigenetic regulation by the menin pathway. Endocrine-Related Cancer 201724 T147-T159.
254 Baradari V, Huether A, Hopfner M, Schuppan D \& Scherubl H. Antiproliferative and proapoptotic effects of histone deacetylase inhibitors on gastrointestinal neuroendocrine tumour cells. Endocrine-Related Cancer 200613 1237-1250. (https://doi. org/10.1677/erc.1.01249)

255 Sun L, Qian Q, Sun G, Mackey LV, Fuselier JA, Coy DH \& Yu CY. Valproic acid induces NET cell growth arrest and enhances tumour suppression of the receptor-targeted peptide-drug conjugate via activating somatostatin receptor type II. Journal of Drug Targeting 201624 169-177. (https://doi.org/10.3109/10611 86X.2015.1066794)

256 Shah MH, Binkley P, Chan K, Xiao J, Arbogast D, Collamore M, Farra Y, Young D \& Grever M. Cardiotoxicity of histone deacetylase inhibitor depsipeptide in patients with metastatic neuroendocrine tumours. Clinical Cancer Research 200612 3997-4003. (https://doi. org/10.1158/1078-0432.CCR-05-2689)

257 Jin N, Lubner SJ, Mulkerin DL, Rajguru S, Carmichael L, Chen H, Holen KD \& LoConte NK. A phase II trial of a histone deacetylase inhibitor panobinostat in patients with low-grade neuroendocrine tumours. Oncologist 201621 785-786. (https://doi.org/10.1634/ theoncologist.2016-0060)

258 Zhang S \& Yu D. Targeting Src family kinases in anti-cancer therapies: turning promise into triumph. Trends in Pharmacological Sciences 2012 33 122-128. (https://doi.org/10.1016/j.tips.2011.11.002)

259 Kuhlmann JD, Hein L, Kurth I, Wimberger P \& Dubrovska A. targeting cancer stem cells: promises and challenges. Anti-Cancer Agents in Medicinal Chemistry 201616 38-58. (https://doi.org/10.2174 /1871520615666150716104152)

260 Islam F, Gopalan V, Smith RA \& Lam AK. Translational potential of cancer stem cells: a review of the detection of cancer stem cells and their roles in cancer recurrence and cancer treatment. Experimental Cell Research 2015335 135-147. (https://doi.org/10.1016/i. yexcr.2015.04.018)

261 Lloyd RV, Hardin H, Montemayor-Garcia C, Rotondo F, Syro LV, Horvath E \& Kovacs K. Stem cells and cancer stem-like cells in endocrine tissues. Endocrine Pathology 201324 1-10. (https://doi. org/10.1007/s12022-013-9235-1)

262 Gaur P, Sceusi EL, Samuel S, Xia L, Fan F, Zhou Y, Lu J, Tozzi F, LopezBerestein G, Vivas-Mejia P, et al. Identification of cancer stem cells in human gastrointestinal carcinoid and neuroendocrine tumours. Gastroenterology 2011141 1728-1737. (https://doi.org/10.1053/j. gastro.2011.07.037)

263 Di Florio A, Adesso L, Pedrotti S, Capurso G, Pilozzi E, Corbo V, Scarpa A, Geremia R, Delle Fave G \& Sette C. Src kinase activity coordinates cell adhesion and spreading with activation of mammalian target of rapamycin in pancreatic endocrine tumour cells. Endocrine-Related Cancer 201118 541-554. (https://doi. org/10.1530/ERC-10-0153)

264 Capurso G, Di Florio A, Sette C \& Delle Fave G. Signalling pathways passing Src in pancreatic endocrine tumours: relevance for possible combined targeted therapies. Neuroendocrinology 201397 67-73. (https://doi.org/10.1159/000336093)

265 Tai YL, Chen LC \& Shen TL. Emerging roles of focal adhesion kinase in cancer. BioMed Research International 20152015690690.

266 Moen I, Gebre M, Alonso-Camino V, Chen D, Epstein D \& McDonald DM. Anti-metastatic action of FAK inhibitor OXA-11 in combination with VEGFR-2 signaling blockade in pancreatic neuroendocrine tumours. Clinical and Experimental Metastasis 2015 32 799-817. (https://doi.org/10.1007/s10585-015-9752-z)

267 Pool SE, Bison S, Koelewijn SJ, van der Graaf LM, Melis M, Krenning EP \& de Jong M. mTOR inhibitor RAD001 promotes metastasis in a rat model of pancreatic neuroendocrine cancer. Cancer Research 201373 12-18. (https://doi.org/10.1158/1538-7445. AM2013-12) http://www.endocrineconnections.org

https://doi.org/10.1530/EC-17-0286
(C) 2018 The authors

Published by Bioscientifica Ltd
This work is licensed under a Creative Commons Attribution-NonCommercial-NoDerivatives 4.0 International License. 
268 Hobday TJ, Qin R, Reidy-Lagunes D, Moore MJ, Strosberg J, Kaubisch A, Shah M, Kindler HL, Lenz HJ, Chen H, et al. Multicenter phase II trial of temsirolimus and bevacizumab in pancreatic neuroendocrine tumours. Journal of Clinical Oncology 201533 1551-1556. (https://doi.org/10.1200/JCO.2014.56.2082)

269 Vijayvergia N, Boland PM, Handorf E, Gustafson KS, Gong Y, Cooper HS, Sheriff F, Astsaturov I, Cohen SJ \& Engstrom PF. Molecular profiling of neuroendocrine malignancies to identify prognostic and therapeutic markers: a Fox Chase Cancer Center Pilot Study. British Journal of Cancer 2016115 564-570. (https://doi. org/10.1038/bjc.2016.229)
270 Kawase A \& Nagai K. Treatment strategy for neuroendocrine carcinoma of the lung. Gan to Kagaku Ryoho 200936 1619-1622.

271 Briest F, Grass I, Christen F, Lewens F, Freitag H, Kaemmerer D, Saenger J, Hummel M, Siegmund B \& Grabowski P. 455 role of MDM2 as therapeutic target in gastroenteropancreatic neuroendocrine neoplasms (GEP-NENs). European Journal of Cancer $2015 \mathbf{5 0}$ 149. (https://doi.org/10.1016/S0959$8049(14) 70581-7)$

272 Thakker RV. Multiple endocrine neoplasia type 1 (MEN1) and type 4 (MEN4). Molecular and Cellular Endocrinology 2014386 2-15. (https:// doi.org/10.1016/j.mce.2013.08.002)

Received in final form 2 October 2017

Accepted 16 November 2017

Accepted Preprint published online 16 November 2017 http://www.endocrineconnections.org https://doi.org/10.1530/EC-17-0286
C) 2018 The authors Published by Bioscientifica Ltd 